\title{
A multidimensional model for green building assessment: a case study of a highest-rated project in Chongqing
}

Article

Accepted Version

Creative Commons: Attribution-Noncommercial-No Derivative Works 4.0

Li, Y., Yu, W., Li, B. and Yao, R. (2016) A multidimensional model for green building assessment: a case study of a highest-rated project in Chongqing. Energy and Buildings, 125. pp. 231-243. ISSN 0378-7788 doi:

https://doi.org/10.1016/j.enbuild.2016.04.055 Available at https://centaur.reading.ac.uk/67436/

It is advisable to refer to the publisher's version if you intend to cite from the work. See Guidance on citing.

To link to this article DOI: http://dx.doi.org/10.1016/j.enbuild.2016.04.055

Publisher: Elsevier

All outputs in CentAUR are protected by Intellectual Property Rights law, including copyright law. Copyright and IPR is retained by the creators or other copyright holders. Terms and conditions for use of this material are defined in the End User Agreement.

www.reading.ac.uk/centaur 
Central Archive at the University of Reading

Reading's research outputs online 


\title{
A multidimensional model for green building assessment: a case study of a highest-rated project in Chongqing
}

\author{
Yongqiang $\mathrm{Li}^{\text {a,b,c }}$; Wei Yu ${ }^{\text {a,b }}$; Baizhan $\mathrm{Li}^{\text {a,b }}$; Runming Yao ${ }^{\text {a,b,c * }}$; \\ ${ }^{a}$ International Joint Laboratory of Green Buildings and Built Environment, Min-
} istry of Education, Chongqing University, Chongqing, 400045, China;

${ }^{b}$ National Centre for International Research of Low-carbon and Green Buildings, Ministry of Science and Technology, Chongqing University, Chongqing 400045, China;

${ }^{c}$ School of the Built Environment, University of Reading, UK

Coresponding author:

*Email: r.yao@cqu.edu.cn; r.yao@ reading.ac.uk. Engineering Building, School of the Built Environment, University of Reading, Whiteknights, Reading, RG6 6AY, UK.

\begin{abstract}
:
Green building is an inevitable trend in the construction industry which deeply affects the social development of the economy, environment and a series of industries. There is practical significance for the multidimensionally balanced development of green buildings. A model for multi-objective assessment of green building is developed under three dimensions: Objective, Professional and Time (OPT) according to the green
\end{abstract}


building definition. The OPT coordinate system was built up based on the scoring centroid system of both the China Green Building Labelling scheme (GBL) and the Singapore Green Mark (GM) by the introduction of the Coefficient of Variation and Moment of Inertia. Both these frameworks are restructured based on a case study of a practical project in Chongqing which had achieved the highest GBL and GM awards. Results show that GBL distributes its scores more evenly while GM concentrates on energy saving with greater diversity in land supply and building operations (normalized coefficients of variation of 0.435 and 0.350 ). The project's compliance coefficients are 1.27 and 0.31 under GBL and GM respectively indicating its higher degree of compliance with the GM framework. The developed model provides multitarget-oriented guidelines for green building design, assessment and standarddevelopment.

Keywords: Green building, Multidimension, Coefficient of Variation, Moment of Inertia, Compliance Coefficient.

\section{Introduction}

Green building has become a critical measure for climate change and sustainable development and has taken responsibility for the long-term balance of economic, environmental and social health [1]. The history of green building design dates back to the late 1980s when sustainability was defined by the United Nations' World Commission on Environment and Development [2]. In the past 50 years, the concept of green building has gradually been established after intensive research and practice [3-6]. The most widely accepted definition of green building is to provide people with healthy, applicable, efficient space and natural harmonious architecture with the maximum savings on resources (energy, land, water, materials), protection for the environment and reduced pollution throughout its whole lifecycle[7-12]. The definition indicates the target requirements for green building objectives, professional skills and time. Many countries have paid great attention to the healthy development of green building[13]. A range of 
green building rating systems, protocols, guidelines and standards has been developed in the past 20 years[14, 15] and around 600 methods of assessment exist today[16] including Building Research Establishment Environmental Assessment Method (BREEAM) in the U.K, Leadership in Energy and Environmental Design (LEED) in the U.S, the Comprehensive Assessment System for Built Environment Efficiency (CASBEE) in Japan, the Green Building Tool (GB-Tool) in Canada, Green Star in Australia, Green Mark (GM) in Singapore, the Hong Kong Building Environmental Assessment Method (HK-BEAM) in Hong Kong, EcoProfile in Norway, Environmental Status in Sweden and the Green Building Labelling scheme (GBL) in China. However, there is no consensus on the best evaluation standard for green building assessment tools[17] as the individual evaluation systems are based on their own regional conditions and characteristics with separate scoring systems. So a lot of related research has been done based on the application and improvement of the various green building standards.

However, most studies aimed at the development of specific standards. Azhar[18] explored the implementation of Building Information Modelling (BIM) technology to help the LEED certification process while Cheng and $\mathrm{Ma}[19]$ studied the relationship between LEED credits in order to simultaneously achieve multiple credits using one type of green building technology. On the technical aspects, Alshamrani[20] explored the possibility of integrating lifecycle assessment (LCA) techniques to achieve higher sustainability levels.

Green building standards have also been widely applied in architectural design. Castro-Lacouture[21] developed an optimization method for the selection of construction materials. Wang[22] developed an object-oriented framework that tackles specific problem areas related to green building design optimization. A methodology was developed to optimize the building shapes using genetic algorithms by the introduction of lifecycle investment and lifecycle environmental impact as two objective functions for green performance evaluation. Schiavon and Altomonte[23] studied the indirect influential factors, such as office type and building size, in the achievement of indoor environment quality (IEQ). 
More and more theoretical models involving all building aspects have been developed. Günaydın and Doğan[24] developed a neural network model for 30 residential building projects to estimate cost per unit area. Kim[25] used three different prediction models: neural network, regression analysis and case-based reasoning, to predict the cost of 530 local buildings in Korea. Emsley[26] developed an ANN model to predict building cost by utilizing a project's strategic, site-related and design-related variables.

Green building adoptions have been largely explored. Reith et al [27] compared five assessment systems including CASBEE-UD, the 2009 and 2012 versions of the BREEAM Communities, LEED-ND, and DGNB-UD and provide information about the similarities, differences, and working methods of the systems, and guidance in choosing a proper assessment system for a specific development. Kennedy et al [28] developed an artificial neural network model (generic 7-6-4 neurons layered architecture) in predicting indices, based on certain social conditions, on the choice of certain low carbon technologies. Shin et al [29] developed a method to assess the amount of carbon dioxide $\left(\mathrm{CO}_{2}\right)$ emitted during the production of construction materials, and arose a system for evaluating the environmental load of construction during architectural planning and basic design phases. Zhao et al[30] analyzed the social problems of green buildings from the humanistic needs to social acceptance. Lee et al [31]provide the green template focusing on embodied environmental impact for lifecycle assessment of buildings based on building information modeling.

Meanwhile, researachers began to look into the limitations in the historical process of the green building development. Dean et al [32] find that major real-estate developers of business parks around the world have made environmental responsibility a priority in building design, construction, and operation, so they promoted the EBOM model to help companies gauge the goal of environmental stewardship. Zhang et al[33] find that there is lack of a systematic review of this large number of studies that is critical for the future endeavor. It is found that the existing studies mainly focus on the environmental aspect of green building while other dimensions of sustainability of green building, especially the social sustainability is largely over looked. Their study also 
announced future research opportunities were identified such as the innovation of evaluation systems, integration of planning and design frameworks, management mechanisms and financing modes, and future proofing[33].

In conclusion, the current studies for green buildings mainly concentrate on energy efficiency, technical analysis, economic analysis, productivity, satisfaction, health and thermal comfort, but rarely involve the inner balanced evaluation[18-23]. This results in a phenomenon whereby projects are pursuing the final score as the only motivation rather than seeking to achieve a comprehensive green design. It is common that construction projects are driven by the purpose of increasing the rating scores during the green building assessment without investigation on the resource effectiveness and environmental performance. Therefore, a holistic assessment system is desired to provide technical support for the judicious decision on the measures taken in order to achieve the green building assessment target.

The aim of this research is to develop a holistic method with a horizontal and vertical dimensional framework for the green building assessment. The method should be able to reflect the inner-relationship of dimensions in order to balance the Objective; Professional and Time dimensions (OPT) of the Green Building.

\section{Research methodology}

The research design has three aspects:

(1) to investigate the specific characteristics and balance of the assessment criteria of the two Green Building Assessment methods through a case study. A real project in Chongqing is selected which has won the highest rate of both GBL and GM. The reasons of the choices of this project are: 1) the project attempted to achieve the highest level in both standards with implementations of a large number of green technologies. The application of the wide range of technologies will eliminate random errors of potential scoring difference due to the insuficient coverage of green technologies; and 2) defferent green building assessment methods have their own characteristics due to many factors such as 
policy, economic development, geographical environment, climate conditions, natural resources structures, technology availability and so on. The same building using different assessment methods could lead to different building design and performance. This real project has been awarded the highest ratings, namely a Platinum Award of the Singapore GM and a 3-Star Award of the China GBL, which offers an excellent opportunity for comapritive studies in order to test their inner balance in OPT dimensions.

(2) to analyse the score distribution of the OPT dimensions based on the green building definition as set out in the original targets; and

(3) to develop a method of evaluating a green project's comprehensive compliance level with a specific green building standard.

\subsection{Evaluation process of green building by GBL \& GM}

Evaluation of green building using GBL is divided into two phases, namely the design and operation phases. Operation stage evaluation is to be carried out one year after the building has begun to be used. The GM evaluation process is not divided into different phases and projects in the design stage can also apply for certification under a pre-assessment procedure. GM sets mandatory on-site examination requirements after project completion to ensure the implementation of the indicators and designs described in the pre-assessment process. The detailed assessment processes of GBL and GM are shown in Fig. 1. 


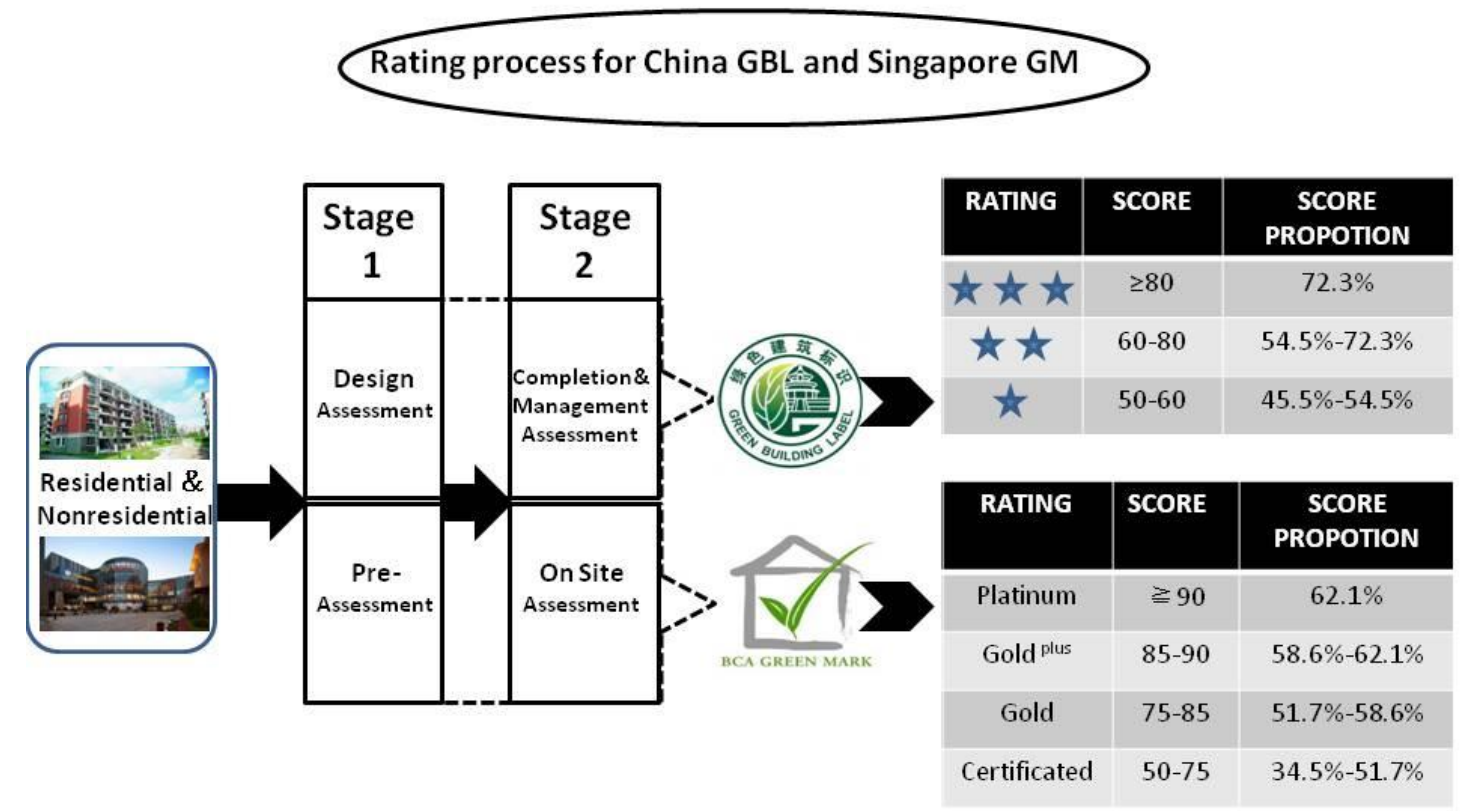

Fig.1: Assessment framework for GBL and GM

A project applying for China GBL is required to have a self-assessment before delivering all the certificate materials and technical reports to the China Green Building Council. The China Green Building Council arranges the meeting for the project to examine the supporting documents. Building engineering experts will be invited to meet together with the project owners, the construction side, the designer and consultants, etc. A final score will be achieved and the project is required to supply extra materials after the meeting in response to the experts' questions. Projects applying for GM are also required to have self-assessment and complete the official forms of the Singapore Building and Construction Authority (BCA). A presentation has to be made to the expert committee and the projects which have passed pre-assessment will be authorized with GM Labelling.

\subsection{Score distribution of GBL \& GM}

The GM has five assessment criteria including energy saving, water saving, environmental protection, indoor environment and other environmental measures whilst the GBL includes land saving, energy saving, water saving, material saving and indoor environment. Figure 2 shows the proportion of the assessment criteria of both schemes. 
From the figure we can see that there is a significant gradient among scores for each item under GM although it covers many indicators. The evaluation of the energy efficiency accounts for $58 \%$ thereby showing its great concern with energy saving. This is in line with the national characteristics of Singapore as an island country with cautious in natural resources, particularly energy resources. The category distribution in GBL is more evenly and "overall balanced" compared to GM.

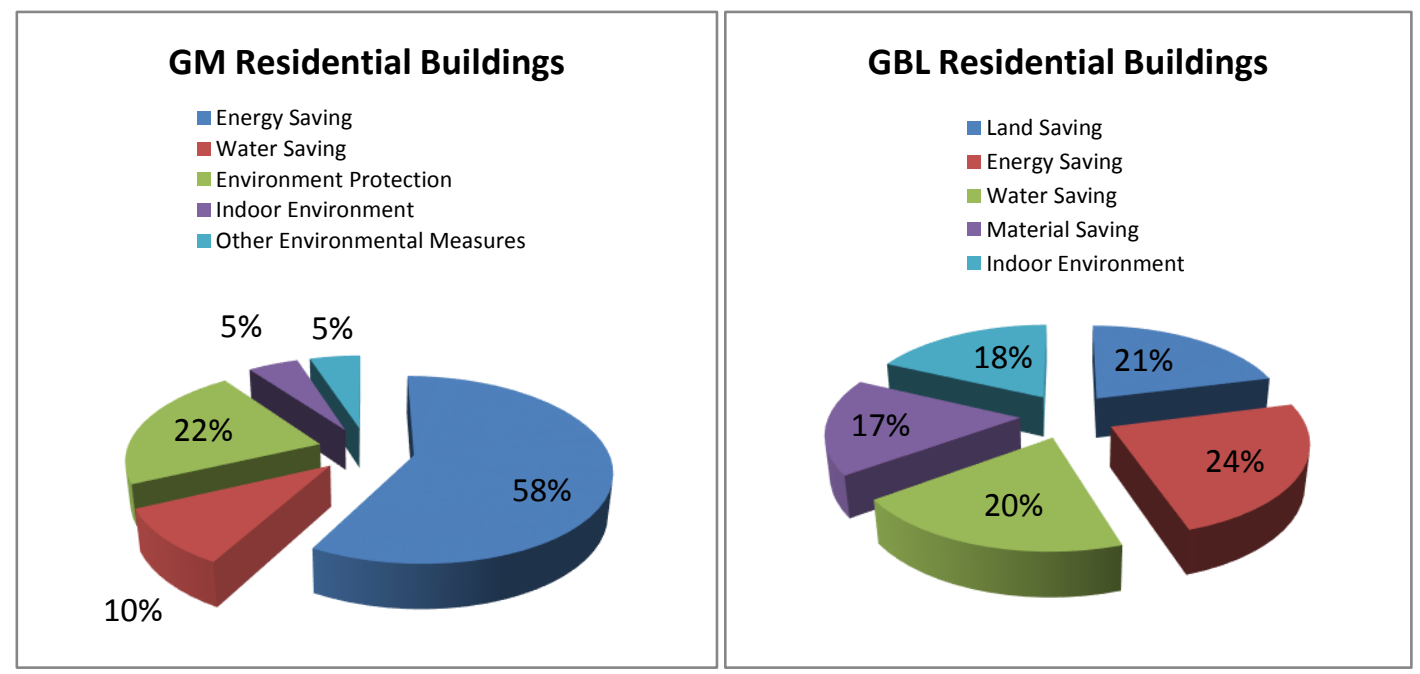

Fig. 2: The categories and score distribution of China GBL and Singapore GM

For a more objective comparison, the GM score distribution is converted into the GBL framework of land saving, energy saving, water saving, material saving and indoor environment. The GM scores in the "environmental protection" and "other environmental measures" items are decomposed and reassigned into other categories in GBL. The result is shown in Fig. 3 reflecting the main items of both green building standards. As can be seen in Fig. 3, GM pays great attention to energy saving whilst relatively neglecting the indoor environment and 'other' items. 


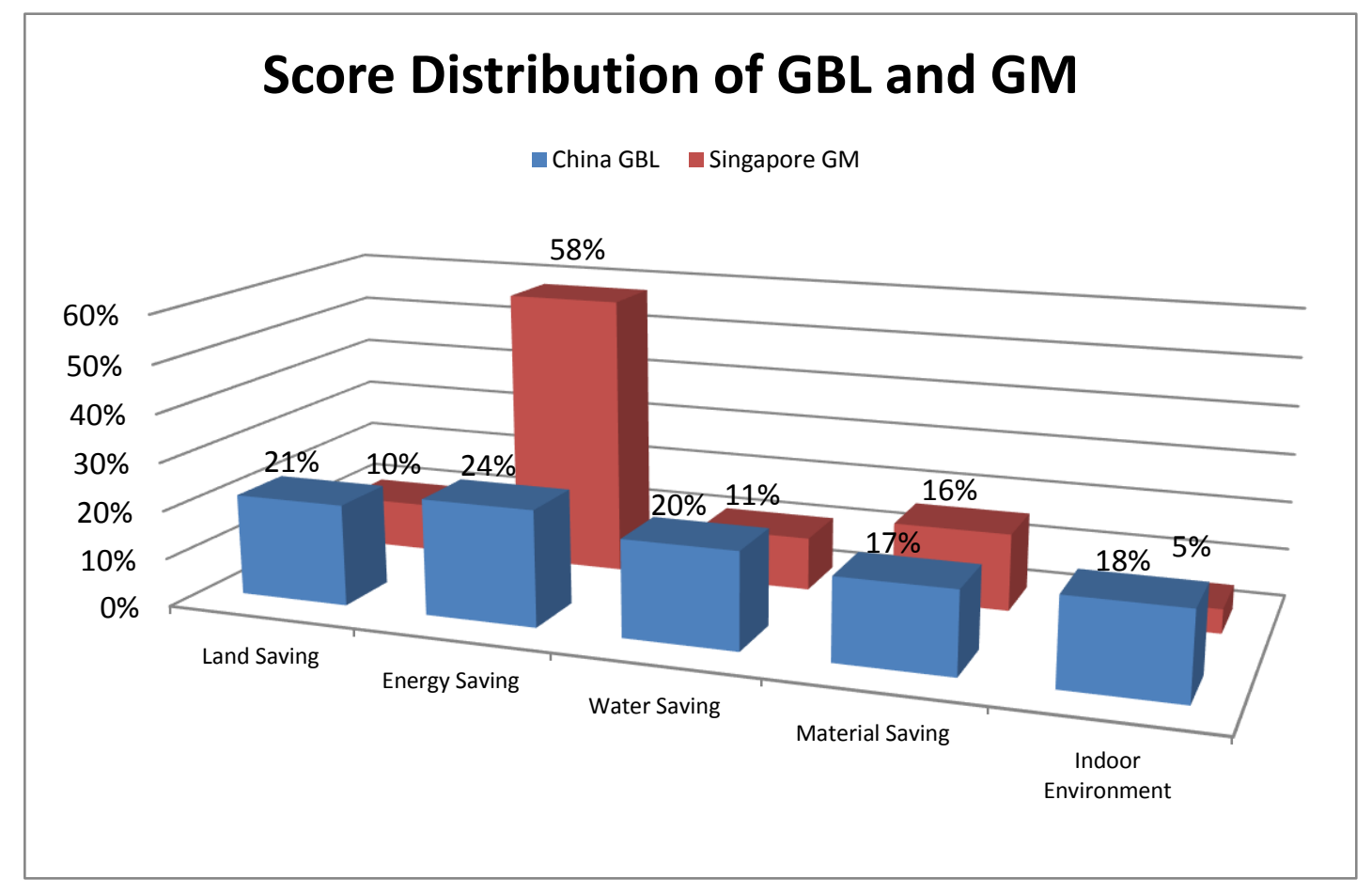

Fig. 3: Comparison of score distribution of China GBL and Singapore GM

\section{Information on the case study project}

\subsection{Project information}

The project is a cluster of multi-residential buildings which is under construction until 2017. Fig. 4 shows the green features of the project and the construction site. A variety of green technologies were considered and the project has passed the GM preassessment in July 2014 and the GBL design stage assessment in November 2015. Detailed green features of the project are shown in Table 1. 


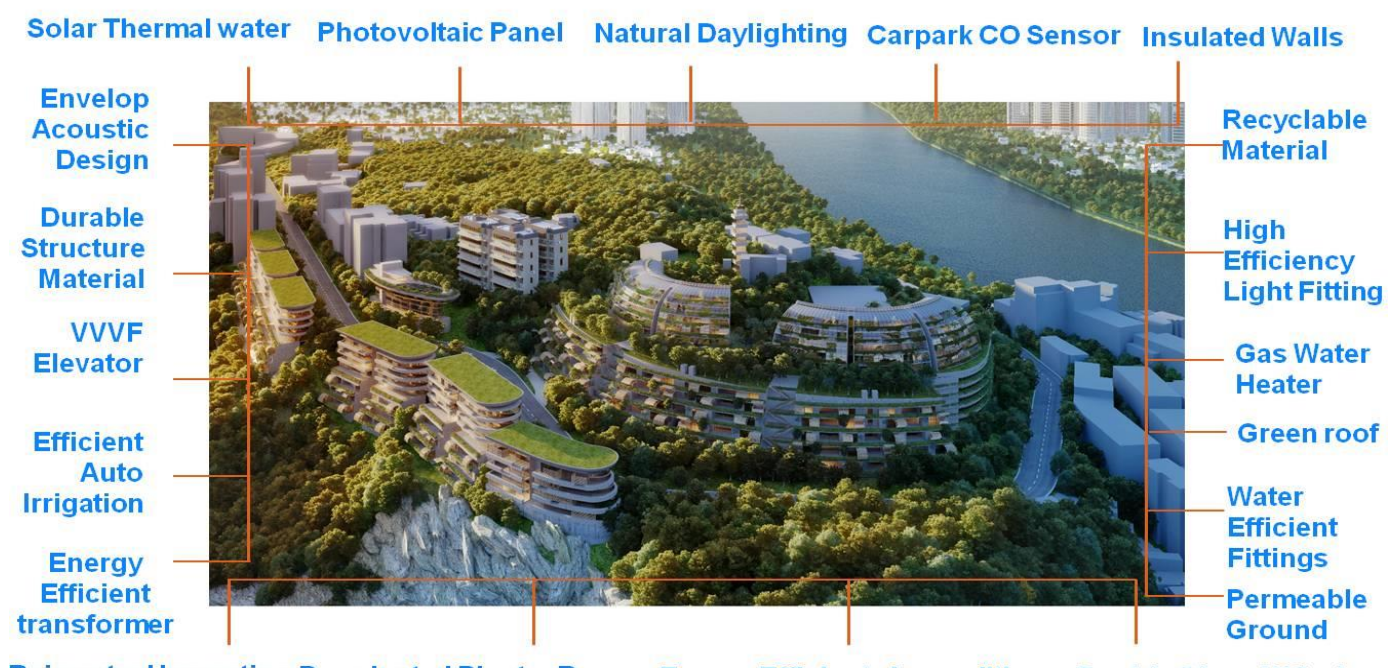

Rainwater Harvesting Pre-planted Planter Boxes Energy Efficient air-conditioner Double Glazed Window
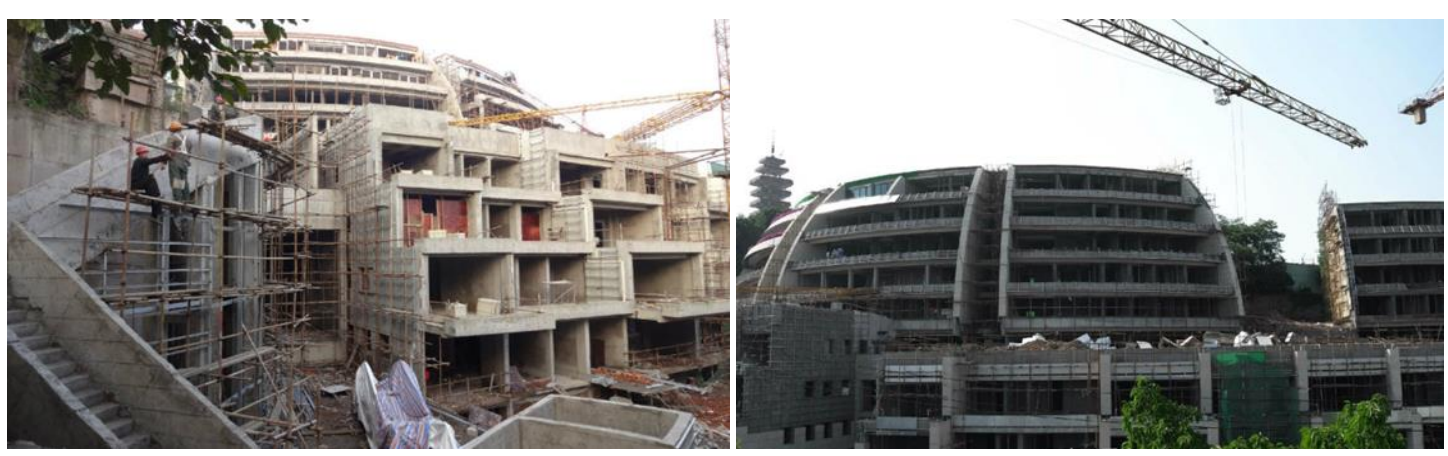

Fig. 4: Main Green features of the project and the construction site in August, 2015

Table 1: Green features of the project

\begin{tabular}{c|l}
\hline Green features & \multicolumn{1}{c}{ Specific building technologies or indicators } \\
\hline Building Envelope Design & Energy efficiency rate of $67 \%$ \\
\hline Indoor Comfort & First Grade Energy-efficient air conditioners \\
\hline Natural Ventilation in Public Areas & Natural ventilation available for $80 \%$ of the public areas \\
\hline Efficient Artificial Lighting in Public & Elevator room of $2.61 \mathrm{~W} / \mathrm{m}^{2}$, staircase of $3.17 \mathrm{~W} / \mathrm{m}^{2}$, under- \\
Natural Daylighting in Public Areas- & Underground car park with natural lighting in day time \\
Light Wells & (approximately $1500 \mathrm{~m}^{2}$ ) \\
\hline Ventilation in Underground car park & Linkage of mechanical ventilation and carbon monoxide \\
\hline
\end{tabular}




\begin{tabular}{|c|c|c|}
\hline & \multicolumn{2}{|l|}{ sensor } \\
\hline Lifts - All with VVVF \& Sleep Mode & \multicolumn{2}{|c|}{$\begin{array}{l}\text { VVVF Motor, gearless traction, centralized control and } \\
\text { group control }\end{array}$} \\
\hline Energy Efficient Features & \multicolumn{2}{|c|}{ Energy Efficiency Index of $32.47 \mathrm{kWh} / \mathrm{m}^{2} / \mathrm{yr}$} \\
\hline Renewable Energy & \multicolumn{2}{|c|}{$\begin{array}{l}\text { Solar hot water }(30.4 \mathrm{~kW}), \mathrm{PV} \text { assisting landscape lighting } \\
(3.146 \mathrm{~kW})\end{array}$} \\
\hline Water Efficiency & \multicolumn{2}{|c|}{ First grade and second grade water-saving appliances } \\
\hline Water Usage Monitoring & \multicolumn{2}{|c|}{ Sub-metering water usage } \\
\hline Rainwater Harvesting & \multicolumn{2}{|c|}{ Designed rainwater harvesting capacity of $5.5 \mathrm{~m}^{3} /$ day } \\
\hline Efficient Auto Irrigation & \multicolumn{2}{|c|}{ Sprinkler and micro sprinkler irrigation } \\
\hline Sustainable Construction Material & \multicolumn{2}{|c|}{$\begin{array}{l}\text { Application of the "China ten rings authentication prod- } \\
\text { ucts" and products with recyclable components accounting } \\
\text { for } 30 \% \text { or more }\end{array}$} \\
\hline Greenery & \multicolumn{2}{|c|}{$\begin{array}{l}\text { Green rate of } 36.10 \% \text {, Greenery Provision }(\mathrm{GnP})=13.2> \\
4.0\end{array}$} \\
\hline $\begin{array}{l}\text { Environmental Management Practice } \\
\text { of Construction process }\end{array}$ & \multicolumn{2}{|c|}{$\begin{array}{l}\text { Construction environmental monitoring and management, } \\
\text { special programmes for green construction (dust control, } \\
\text { noise control, etc.), water and electricity records during } \\
\text { construction, the ISO } 14000 \text { quality system certificated } \\
\text { companies, user instruction, trash classification }\end{array}$} \\
\hline Public Transport Accessibility & \multicolumn{2}{|c|}{ Public transport facilities within 500 metres } \\
\hline Noise Level & \multicolumn{2}{|c|}{$\begin{array}{l}\text { Green belt and ground noise control, building envelope de- } \\
\text { sign for noise insulation }\end{array}$} \\
\hline Indoor Air Quality in Wet Areas & \multicolumn{2}{|c|}{$\begin{array}{l}84 \% \text { of the wet area available for natural ventilation \& nat- } \\
\text { ural lighting }\end{array}$} \\
\hline Green Innovations & \multicolumn{2}{|c|}{$\begin{array}{l}56.82 \% \text { greening roof rate, full heat-exchange unit, Low } \\
\text { Concrete Usage Index (CUI }=0.35) \text {, Pre-planted boxes }\end{array}$} \\
\hline Description & Value & Remarks \\
\hline Constructed Floor Area $\left(\mathrm{m}^{2}\right)$ & 48334.44 & Include all covered area e.g. car \\
\hline
\end{tabular}




\begin{tabular}{|c|c|c|}
\hline & & park \\
\hline $\begin{array}{l}\text { Cost increase due to better glass fa- } \\
\text { çade to achieve better ETTV / RETV } \\
\text { (SGD) }\end{array}$ & $19,615,100$ & $\begin{array}{l}\text { e.g. double or triple glazed façade } \\
\text { system }\end{array}$ \\
\hline $\begin{array}{c}\% \text { increase in construction cost due to } \\
\text { use of better glass (\%) }\end{array}$ & $3.42 \%$ & l \\
\hline $\begin{array}{l}\text { Overall \% increase in construction } \\
\text { cost due to green features }(\%)\end{array}$ & $0.67 \%$ & l \\
\hline Payback period (years) & 9 & $\frac{\text { Incremental Cost }}{\text { Potential Saving/yr }}$ \\
\hline Key KPIs & Estimated & Remarks \\
\hline & 29.82 & $\begin{array}{c}\% \text { saving compared to code compli- } \\
\text { ance building }\end{array}$ \\
\hline Energy Saving & $3.41 \mathrm{E}+05$ & $\begin{array}{c}\text { kWh energy saving per year } \\
(\mathrm{kWh} / \mathrm{yr})\end{array}$ \\
\hline & $20.46 \mathrm{E}+04$ & $\begin{array}{c}¥ \text { savings per year (According to } \\
\text { Chongqing) }\end{array}$ \\
\hline $\mathrm{CO}_{2}$ emission reduction per year & $1.57 \mathrm{E}+03$ & $\begin{array}{l}\text { Express in tonnes of } \mathrm{CO}_{2} \text {. (assume } \\
500 \mathrm{~g} \text { of } \mathrm{CO}_{2} \text { produced for every } \\
\mathrm{kWh} \text { electricity consumed. } 1 \text { tonne } \\
\text { of } \mathrm{CO}_{2} \text { is equivalent to } 1000 \mathrm{~kg} \text { of } \\
\left.\qquad \mathrm{CO}_{2}\right)\end{array}$ \\
\hline Renewable energy & $8.90 \mathrm{E}+04$ & $\mathrm{kWh}$ collected per year \\
\hline \multirow{4}{*}{ Water Saving } & 3.65 & $\begin{array}{l}\% \text { saving compared to code compli- } \\
\text { ance building (operational phase) }\end{array}$ \\
\hline & 3076.95 & $\begin{array}{c}\text { Cubic metre saving per year }\left(\mathrm{m}^{3} / \mathrm{yr}\right) \\
\text { (operational phase) }\end{array}$ \\
\hline & $0.65 \mathrm{E}+04$ & RMB savings per year \\
\hline & 0.138 & $\begin{array}{c}\mathrm{RMB} / \mathrm{m}^{3} \text { (RMB saving per cubic } \\
\text { metre) }\end{array}$ \\
\hline
\end{tabular}




\begin{tabular}{c|c|c}
\hline Expected annual cost savings (RMB) & $21.11 \mathrm{E}+04$ & Energy + Water savings \\
\hline Water saving (construction usage) & 2008 & $\begin{array}{c}\text { Cubic metre saving per year (con- } \\
\text { struction phase usage) }\end{array}$ \\
\hline
\end{tabular}

\subsection{Scoring system}

The project achieves a final score of 102 points in GM and 83 points in GBL. Detailed score distributions of the project under GM and GBL are shown in Table 2.

Table 2: Project score distribution under GM and GBL

\begin{tabular}{|c|c|c|c|c|c|c|c|}
\hline \multirow{3}{*}{$\begin{array}{l}\text { GM } \\
102\end{array}$} & Items & $\begin{array}{l}\text { Energy } \\
\text { saving }\end{array}$ & $\begin{array}{l}\text { Water } \\
\text { saving }\end{array}$ & $\begin{array}{l}\text { Indoor } \\
\text { environ- } \\
\text { ment }\end{array}$ & $\begin{array}{l}\text { Environ- } \\
\text { mental pro- } \\
\text { tection }\end{array}$ & $\begin{array}{l}\text { Other Environ- } \\
\text { mental } \\
\text { measures }\end{array}$ & $\begin{array}{c}\text { Renewable } \\
\text { (Bonus } \\
\text { score) }\end{array}$ \\
\hline & Score & 53.5 & 11 & 4.5 & 19 & 3 & 11 \\
\hline & $\begin{array}{c}\text { Pro- } \\
\text { portion }\end{array}$ & 0.52 & 0.11 & 0.44 & 0.19 & 0.03 & 0.11 \\
\hline \multirow{3}{*}{$\begin{array}{c}\text { GBL } \\
83\end{array}$} & Items & $\begin{array}{l}\text { Energy } \\
\text { saving }\end{array}$ & $\begin{array}{l}\text { Water } \\
\text { saving }\end{array}$ & $\begin{array}{l}\text { Indoor } \\
\text { environ- } \\
\text { ment }\end{array}$ & $\begin{array}{l}\text { Land sav- } \\
\text { ing }\end{array}$ & Material saving & $\begin{array}{c}\text { Innovations } \\
\text { (Bonus } \\
\text { score) }\end{array}$ \\
\hline & Score & 19.44 & 15.6 & 14.04 & 15.75 & 9.35 & 9 \\
\hline & $\begin{array}{c}\text { Pro- } \\
\text { portion }\end{array}$ & 0.23 & 0.19 & 0.17 & 0.19 & 0.11 & 0.11 \\
\hline
\end{tabular}

The project under GM got 64.5 points in the energy saving category whose contribution ratio reached $62.6 \%$ whilst that of GBL only reached $23.1 \%$. Similarly, there are differences in the indoor environment item with $4.4 \%$ for GM, and $17.8 \%$ for GBL.

\section{Development of the holistic method}

The study is conducted with the introduction of the coefficient of variation (CV) and moment of inertia (MI) to decouple and restructure the main indicators. Both GM and GBL are composed of five main indicators with detailed secondary indicators 
which refer to the separate green technologies. The green technologies can be divided into different aspects of the objective targets (energy saving target, land saving target, water saving target, materials saving target, environmental protection target, comfortable and efficient target), professional targets (planning, architecture, structure, materials, HVAC, drainage works, electrical engineering) and time targets (site preparation, project approval, planning, design, review, construct, completion \& detect). Different targets are transferred into three dimensions to develop an OPT coordinate system. The analysis of the coefficient of variation $(\mathrm{CV})$ is carried out for both GM and GBL to reveal the in-depth structural features of both standards. The concept of 'moment of inertia' (MI) is introduced to develop the model for calculating the project's compliance degree for specific green building standards.

The coefficient of variation is originally an important dimensionless statistical parameter $[34,35]$. Though some other statistics, such as standard deviation and skewness, can also be used as measure of data distribution, they have been demonstrated no better than the performance of CV[36]. Since CV is a dimensionless measure that can be used to compare the variation of data sets with significant different cluster sizes. Generally, the larger the CV value is, the greater the variability is in the data[37]. It has won its advantages in cross concept analysis and been widely applied in biomedicine, environmental analysis, manufacturing, dynamics study and many other fields [38-43]. The traditional analysis based on standard deviation (SD) reflects the degree of fluctuation of a random variable. However, it sometimes produces unreasonable phenomena[44, 45]. The reasons are: 1) if the random variables are with the different dimensions, there is no practical significance for comparison. 2) If the random variables are with the same dimension, the relative size of the two random variables brings about a problem that random variables with larger values allow for a greater SD. The introduction of the $\mathrm{CV}$ in the comparison of volatility between GM and GBL is a more reasonable solution to the problem. The moment of inertia is a physics concept presenting the rotating status of a rigid body. The MI of a rigid body or mass system, originally a physical concept, has been introduced as an important parameter in various areas of scientific experiments, engineering, aerospace, biological researchand other industrial and social practices [46- 
50]. It is irrelevant to the rotation status about an axis (such as the angular velocity) in thea mass system which is an appropriate description for the compliance degree analysis in this study.

\subsection{Decoupling of the Multi-dimensional system}

The objective dimension of the OPT system contains Land saving (O1), Water saving (O2), Energy saving (O3), Material saving (O4), Environment protection (O5), Indoor environment (O6) and Operation and comprehensiveness (O7). The professional dimension contains Planning (P1), Architecture (P2), Structure (P3), Materials (P4), HVAC (P5), Drainage works (P6) and Electrical Engineering (P7). The time dimension contains Land permission (T1), Project approval (T2), Planning (T3), Design (T4), Review (T5), Construct (T6) and Completion \& Test (T7). Detailed multi-dimensional dismantling is shown in Table 3.

Table 3: Multidimensional dismantling for items in the green building evaluation system

\begin{tabular}{|c|c|c|c|c|c|c|c|c|}
\hline \multirow[t]{2}{*}{$\mathrm{O}$} & Name & $\begin{array}{l}\text { Land } \\
\text { saving }\end{array}$ & $\begin{array}{l}\text { Water } \\
\text { saving }\end{array}$ & $\begin{array}{l}\text { Energy } \\
\text { saving }\end{array}$ & $\begin{array}{c}\text { Mate- } \\
\text { rial } \\
\text { saving }\end{array}$ & $\begin{array}{c}\text { Environ- } \\
\text { mental pro- } \\
\text { tection }\end{array}$ & $\begin{array}{c}\text { Indoor } \\
\text { environ- } \\
\text { ment }\end{array}$ & $\begin{array}{l}\text { Operation } \\
\text { and compre- } \\
\text { hensiveness }\end{array}$ \\
\hline & $\begin{array}{l}\text { Coor- } \\
\text { dinate }\end{array}$ & $\mathrm{O} 1$ & $\mathrm{O} 2$ & $\mathrm{O} 3$ & $\mathrm{O} 4$ & O5 & O6 & O7 \\
\hline \multirow[t]{2}{*}{$\mathrm{P}$} & Name & $\begin{array}{l}\text { Plan- } \\
\text { ning }\end{array}$ & $\begin{array}{l}\text { Archi- } \\
\text { tecture }\end{array}$ & $\begin{array}{l}\text { Struc- } \\
\text { ture }\end{array}$ & $\begin{array}{l}\text { Mate- } \\
\text { rials }\end{array}$ & HVAC & $\begin{array}{c}\text { Drainage } \\
\text { works }\end{array}$ & $\begin{array}{l}\text { Electrical } \\
\text { Engineer- } \\
\quad \text { ing }\end{array}$ \\
\hline & $\begin{array}{l}\text { Coor- } \\
\text { dinate }\end{array}$ & $\mathrm{P} 1$ & P2 & P3 & P4 & P5 & P6 & P7 \\
\hline \multirow[t]{2}{*}{$\mathrm{T}$} & Name & $\begin{array}{l}\text { Site } \\
\text { prepa- } \\
\text { ration }\end{array}$ & $\begin{array}{l}\text { Project } \\
\text { ap- } \\
\text { proval }\end{array}$ & Plan & Design & Review & $\begin{array}{c}\text { Construc- } \\
\text { tion }\end{array}$ & $\begin{array}{c}\text { Completion } \\
\& \text { Detect }\end{array}$ \\
\hline & $\begin{array}{l}\text { Coor- } \\
\text { dinate }\end{array}$ & $\mathrm{T} 1$ & $\mathrm{~T} 2$ & $\mathrm{~T} 3$ & $\mathrm{~T} 4$ & T5 & T6 & $\mathrm{T} 7$ \\
\hline
\end{tabular}


Take the secondary indicator " $1-4 a$ " in GM as an example, the description "Encourage the use of more efficient lighting or daylighting in public areas to minimise energy consumption from lighting usage while maintaining proper luminance level" and the requirements "Artificial lighting in common areas should achieve the Baseline $=$ Maximum lighting power budget stated in SS 530 and GB 50034, the points awarded $=0.3^{*}$ (\% improvement) (Up to 12 points)" makes the indicator classified in $\mathrm{O} 3, \mathrm{P} 7$, T7. The secondary indicator " $1-4 a$ " falls into the energy saving targets in the Objective dimension, electrical engineering targets in the Professional dimension and design targets in the Time dimension with the actual score of 10 points (total score of 12 points). It represents a mass point with weight of 10 (12 in total) and the coordinate position of $(3,7,7)$. Detailed score decoupling of the GM and GBL is shown in Table 4 and Table 5.

Table 4: Indicator dismantling of the project under GM in the OPT coordinate system

\begin{tabular}{lllllll}
\hline Items & Secondary & Objective & Professional & Time co- & Actual & Total \\
& indicators & coordinate & coordinate & ordinate & score & score \\
\hline Energy & 1.1 & O3 & P3 & T2 & 11.5 & 20 \\
Efficiency & $1.2 \mathrm{a}$ & $\mathrm{O} 3$ & $\mathrm{P} 7$ & $\mathrm{~T} 6$ & 8 & 8 \\
& $1.2 \mathrm{~b}$ & $\mathrm{O} 3$ & $\mathrm{P} 1$ & $\mathrm{~T} 3$ & 4 & 4 \\
& 1.3 & $\mathrm{O} 3$ & $\mathrm{P} 2$ & $\mathrm{~T} 4$ & 2 & 2 \\
& $1.4 \mathrm{a}$ & $\mathrm{O} 3$ & $\mathrm{P} 7$ & $\mathrm{~T} 7$ & 10 & 12 \\
& $1.4 \mathrm{~b}$ & $\mathrm{O} 3$ & $\mathrm{P} 7$ & $\mathrm{~T} 4$ & 3 & 3 \\
& $1.4 \mathrm{c}$ & $\mathrm{O} 3$ & $\mathrm{P} 1$ & $\mathrm{~T} 3$ & 2 & 2 \\
1.5 & $\mathrm{O} 3$ & $\mathrm{P} 5$ & $\mathrm{~T} 5$ & 6 & 8 \\
1.6 & $\mathrm{O} 3$ & $\mathrm{P} 7$ & $\mathrm{~T} 6$ & 2 & 2 \\
$1.7 \mathrm{a}$ & $\mathrm{O} 3$ & $\mathrm{P} 5$ & $\mathrm{~T} 5$ & 0.5 & 1 \\
$1.7 \mathrm{~b}$ & $\mathrm{O} 3$ & $\mathrm{P} 7$ & $\mathrm{~T} 5$ & 1 & 1 \\
& $\mathrm{O} 3$ & $\mathrm{P} 7$ & $\mathrm{~T} 4$ & 1 & 2
\end{tabular}




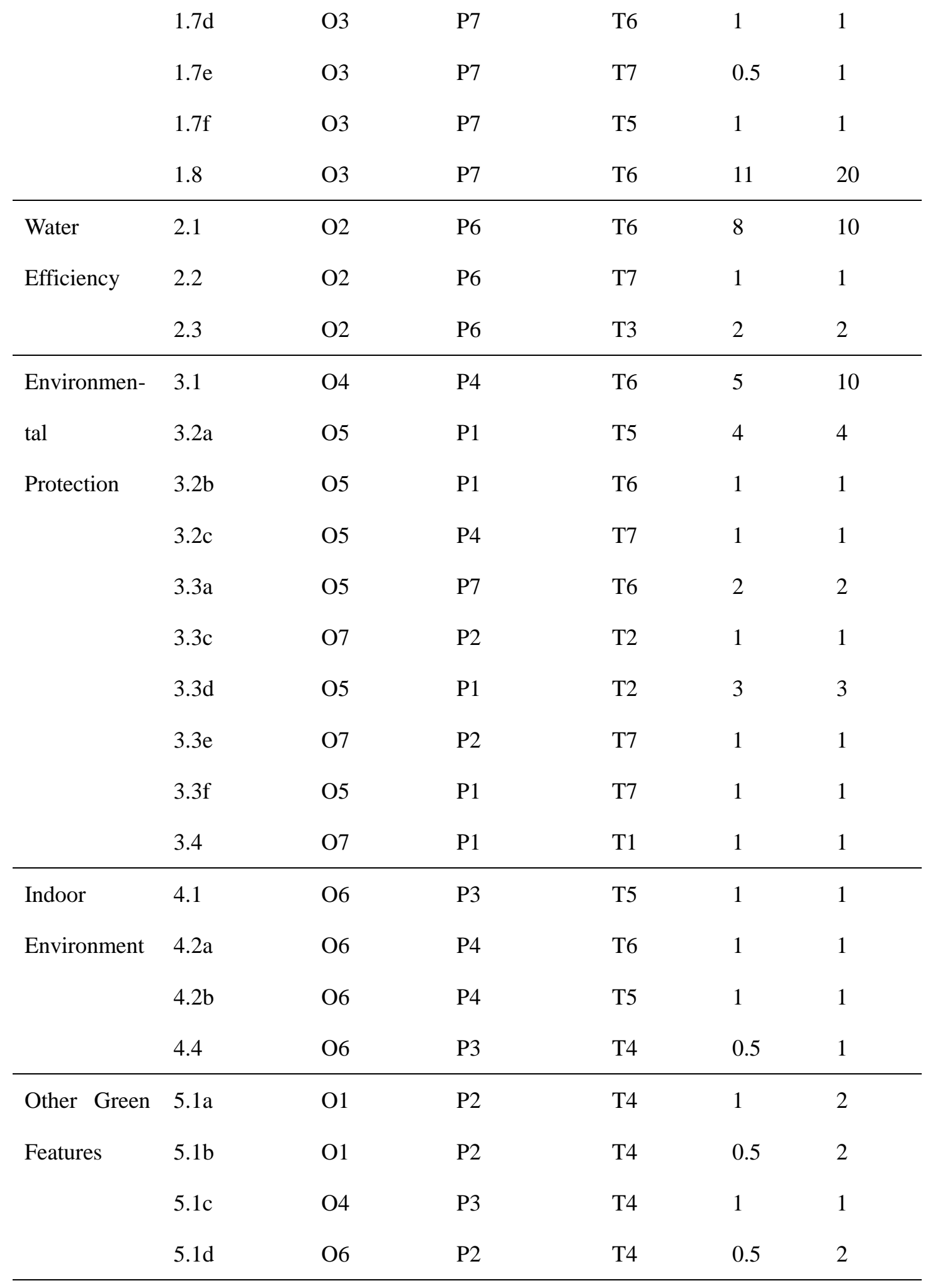

Table 5: Indicator dismantling of the project under GBL in the OPT coordinate system

\begin{tabular}{|c|c|c|c|c|c|c|}
\hline Items & $\begin{array}{l}\text { Secondary } \\
\text { indicators }\end{array}$ & $\begin{array}{l}\text { Objective } \\
\text { coordinate }\end{array}$ & Profes- & $\begin{array}{l}\text { Time co- } \\
\text { ordinate }\end{array}$ & $\begin{array}{l}\text { Actual } \\
\text { score }\end{array}$ & $\begin{array}{l}\text { Total } \\
\text { score }\end{array}$ \\
\hline
\end{tabular}




\begin{tabular}{|c|c|c|c|c|c|c|}
\hline \multirow[b]{2}{*}{ Land Saving \& } & \multirow{3}{*}{$\begin{array}{l}4.2 .1 \\
4.2 .2\end{array}$} & \multirow{3}{*}{$\begin{array}{l}\mathrm{O} 1 \\
\mathrm{O} 1\end{array}$} & \multicolumn{2}{|c|}{$\begin{array}{l}\text { sional coor- } \\
\text { dinate }\end{array}$} & \multirow[b]{2}{*}{0} & \multirow[b]{2}{*}{3.99} \\
\hline & & & $\mathrm{P} 2$ & $\mathrm{~T} 2$ & & \\
\hline Outdoor Envi- & & & $\mathrm{P} 1$ & $\mathrm{~T} 3$ & 1.89 & 1.89 \\
\hline \multirow[t]{13}{*}{ ronment } & 4.2 .3 & $\mathrm{O} 1$ & $\mathrm{P} 3$ & $\mathrm{~T} 2$ & 1.26 & 1.26 \\
\hline & 4.2 .4 & O5 & $\mathrm{P} 2$ & $\mathrm{~T} 4$ & 0.84 & 0.84 \\
\hline & 4.2 .5 & O5 & $\mathrm{P} 1$ & $\mathrm{~T} 5$ & 0.84 & 0.84 \\
\hline & 4.2 .6 & $\mathrm{O} 1$ & $\mathrm{P} 1$ & $\mathrm{~T} 5$ & 1.26 & 1.26 \\
\hline & 4.2 .7 & $\mathrm{O} 1$ & $\mathrm{P} 1$ & $\mathrm{~T} 3$ & 0.84 & 0.84 \\
\hline & 4.2 .8 & $\mathrm{O} 7$ & $\mathrm{P} 1$ & $\mathrm{~T} 1$ & 1.89 & 1.89 \\
\hline & 4.2 .9 & $\mathrm{O} 7$ & $\mathrm{P} 1$ & $\mathrm{~T} 3$ & 0.63 & 0.63 \\
\hline & 4.2 .10 & $\mathrm{O} 1$ & $\mathrm{P} 2$ & $\mathrm{~T} 4$ & 1.26 & 1.26 \\
\hline & 4.2 .11 & $\mathrm{O} 7$ & $\mathrm{P} 1$ & $\mathrm{~T} 2$ & 1.26 & 1.26 \\
\hline & 4.2 .12 & $\mathrm{O} 1$ & $\mathrm{P} 1$ & $\mathrm{~T} 3$ & 0.63 & 0.63 \\
\hline & 4.2 .13 & $\mathrm{O} 2$ & P6 & $\mathrm{T} 3$ & 1.26 & 1.89 \\
\hline & 4.2 .14 & $\mathrm{O} 1$ & P6 & $\mathrm{T} 3$ & 0.63 & 1.26 \\
\hline & 4.2 .15 & O5 & $\mathrm{P} 1$ & $\mathrm{~T} 3$ & 1.26 & 1.26 \\
\hline Energy Saving \& & 5.2 .1 & $\mathrm{O} 3$ & $\mathrm{P} 2$ & $\mathrm{~T} 4$ & 1.44 & 1.44 \\
\hline \multirow[t]{11}{*}{ Energy Use } & 5.2 .2 & O6 & P3 & $\mathrm{T} 4$ & 1.44 & 1.44 \\
\hline & 5.2 .3 & $\mathrm{O} 3$ & P3 & $\mathrm{T} 5$ & 2.4 & 2.4 \\
\hline & 5.2 .4 & $\mathrm{O} 3$ & P5 & $\mathrm{T} 5$ & 1.44 & 1.44 \\
\hline & 5.2 .5 & $\mathrm{O} 3$ & P5 & $\mathrm{T} 4$ & 2.4 & 2.4 \\
\hline & 5.2 .6 & $\mathrm{O} 3$ & P5 & $\mathrm{T} 4$ & 1.44 & 1.44 \\
\hline & 5.2 .7 & $\mathrm{O} 3$ & P5 & $\mathrm{T} 4$ & 2.16 & 2.16 \\
\hline & 5.2 .8 & $\mathrm{O} 3$ & P5 & $\mathrm{T} 4$ & 1.2 & 1.2 \\
\hline & 5.2 .9 & $\mathrm{O} 3$ & P7 & $\mathrm{T} 4$ & 1.92 & 1.92 \\
\hline & 5.2 .10 & $\mathrm{O} 3$ & P7 & $\mathrm{T} 5$ & 0.72 & 0.72 \\
\hline & 5.2 .11 & $\mathrm{O} 3$ & P7 & $\mathrm{T} 4$ & 0.48 & 1.2 \\
\hline & 5.2 .12 & $\mathrm{O} 3$ & P7 & $\mathrm{T} 4$ & 0.72 & 0.72 \\
\hline
\end{tabular}




\begin{tabular}{|c|c|c|c|c|c|c|}
\hline & 5.2 .13 & $\mathrm{O} 3$ & P5 & T6 & 1.68 & 2.4 \\
\hline & 5.2 .14 & $\mathrm{O} 3$ & P5 & $\mathrm{T} 4$ & 1.4 & 1.4 \\
\hline & 5.2 .15 & $\mathrm{O} 3$ & P5 & $\mathrm{T} 4$ & 1.6 & 1.6 \\
\hline & 5.2 .16 & $\mathrm{O} 3$ & $\mathrm{P} 7$ & $\mathrm{~T} 3$ & 1.2 & 1.2 \\
\hline \multirow{12}{*}{$\begin{array}{l}\text { Water Saving \& } \\
\text { Water Use }\end{array}$} & 6.2 .1 & $\mathrm{O} 2$ & $\mathrm{P} 2$ & T5 & 2 & 2 \\
\hline & 6.2 .2 & $\mathrm{O} 2$ & P6 & T6 & 2 & 2 \\
\hline & 6.2 .3 & $\mathrm{O} 2$ & P6 & $\mathrm{T} 7$ & 2 & 2 \\
\hline & 6.2 .4 & $\mathrm{O} 2$ & P6 & $\mathrm{T} 4$ & 1 & 1 \\
\hline & 6.2 .5 & $\mathrm{O} 2$ & P6 & $\mathrm{T} 4$ & 1.4 & 3 \\
\hline & 6.2 .6 & $\mathrm{O} 2$ & P6 & T6 & 1.6 & 1.6 \\
\hline & 6.2 .7 & $\mathrm{O} 2$ & P6 & $\mathrm{T} 4$ & 1.4 & 1.4 \\
\hline & 6.2 .8 & $\mathrm{O} 2$ & P5 & $\mathrm{T} 4$ & 0.51 & 1.53 \\
\hline & 6.2 .9 & $\mathrm{O} 2$ & P6 & $\mathrm{T} 4$ & 0.85 & 0.85 \\
\hline & 6.2 .10 & $\mathrm{O} 2$ & $\mathrm{P} 1$ & $\mathrm{~T} 3$ & 1.02 & 1.7 \\
\hline & 6.2 .11 & $\mathrm{O} 2$ & P5 & $\mathrm{T} 4$ & 0 & 0.85 \\
\hline & 6.2 .12 & $\mathrm{O} 2$ & P6 & $\mathrm{T} 4$ & 1.02 & 1.02 \\
\hline \multirow{13}{*}{$\begin{array}{l}\text { Materials Saving } \\
\text { \& Material Use }\end{array}$} & 7.2.1 & $\mathrm{O} 4$ & P3 & $\mathrm{T} 2$ & 1.7 & 1.7 \\
\hline & 7.2 .2 & $\mathrm{O} 4$ & P3 & $\mathrm{T} 4$ & 0 & 0.85 \\
\hline & 7.2 .3 & $\mathrm{O} 4$ & P2 & $\mathrm{T} 6$ & 1.7 & 1.7 \\
\hline & 7.2.4 & $\mathrm{O} 4$ & P3 & $\mathrm{T} 4$ & 0 & 0.85 \\
\hline & 7.2 .5 & $\mathrm{O} 4$ & P3 & $\mathrm{T} 6$ & 1.7 & 1.7 \\
\hline & 7.2 .6 & $\mathrm{O} 4$ & P2 & $\mathrm{T} 6$ & 0.85 & 0.85 \\
\hline & 7.2 .7 & $\mathrm{O} 4$ & P4 & $\mathrm{T} 2$ & 1.08 & 1.08 \\
\hline & 7.2 .8 & $\mathrm{O} 4$ & P4 & $\mathrm{T} 6$ & 1.26 & 1.62 \\
\hline & 7.2 .9 & $\mathrm{O} 4$ & $\mathrm{P} 4$ & T6 & 0.72 & 0.72 \\
\hline & 7.2 .10 & $\mathrm{O} 4$ & P4 & T6 & 0 & 0.54 \\
\hline & 7.2.11 & $\mathrm{O} 4$ & P4 & $\mathrm{T} 6$ & 1.44 & 1.44 \\
\hline & 7.2 .12 & $\mathrm{O} 4$ & P4 & $\mathrm{T} 6$ & 1.98 & 2.52 \\
\hline & 7.2 .13 & $\mathrm{O} 4$ & $\mathrm{P} 4$ & T6 & 2.16 & 2.16 \\
\hline
\end{tabular}




\begin{tabular}{|c|c|c|c|c|c|c|}
\hline & 7.2.14 & $\mathrm{O} 4$ & $\mathrm{P} 4$ & $\mathrm{~T} 6$ & 1.44 & 1.44 \\
\hline Indoor & 8.2 .1 & O6 & $\mathrm{P} 2$ & $\mathrm{~T} 5$ & 1.8 & 2.34 \\
\hline \multirow[t]{12}{*}{ Environment } & 8.2 .2 & O6 & P3 & $\mathrm{T} 7$ & 1.26 & 1.26 \\
\hline & 8.2 .3 & O6 & $\mathrm{P} 7$ & $\mathrm{~T} 5$ & 0.9 & 0.9 \\
\hline & 8.2 .4 & O6 & P3 & $\mathrm{T} 4$ & 2 & 2 \\
\hline & 8.2 .5 & O6 & $\mathrm{P} 2$ & $\mathrm{~T} 4$ & 1 & 1 \\
\hline & 8.2 .6 & O6 & P7 & $\mathrm{T} 5$ & 1 & 1 \\
\hline & 8.2 .7 & O6 & $\mathrm{P} 2$ & $\mathrm{~T} 4$ & 0 & 1 \\
\hline & 8.2 .8 & O6 & $\mathrm{P} 2$ & $\mathrm{~T} 4$ & 1 & 1 \\
\hline & 8.2 .9 & O6 & P5 & $\mathrm{T} 4$ & 0 & 1 \\
\hline & 8.2 .10 & O6 & P5 & $\mathrm{T} 4$ & 2 & 2 \\
\hline & 8.2 .11 & O6 & $\mathrm{P} 3$ & $\mathrm{~T} 5$ & 0 & 1 \\
\hline & 8.2 .12 & O6 & $\mathrm{P} 7$ & $\mathrm{~T} 4$ & 0 & 2 \\
\hline & 8.2 .13 & O6 & P5 & $\mathrm{T} 4$ & 1 & 1 \\
\hline Improvement \& & 11.2 .1 & $\mathrm{O} 3$ & P5 & $\mathrm{T} 5$ & 1 & 2 \\
\hline \multirow[t]{11}{*}{ Innovation } & 11.2 .2 & $\mathrm{O} 3$ & P5 & $\mathrm{T} 4$ & 0 & 3.99 \\
\hline & 11.2 .3 & $\mathrm{O} 3$ & $\mathrm{P} 7$ & $\mathrm{~T} 2$ & 1.89 & 1.89 \\
\hline & 11.2 .4 & $\mathrm{O} 2$ & P6 & T6 & 1.26 & 1.26 \\
\hline & 11.2 .5 & $\mathrm{O} 4$ & $\mathrm{P} 3$ & $\mathrm{~T} 2$ & 0.84 & 0.84 \\
\hline & 11.2 .6 & O6 & P5 & $\mathrm{T} 4$ & 0.84 & 0.84 \\
\hline & 11.2 .7 & O6 & P4 & $\mathrm{T} 7$ & 1.26 & 1.26 \\
\hline & 11.2 .8 & O5 & $\mathrm{P} 1$ & $\mathrm{~T} 2$ & 0.84 & 0.84 \\
\hline & 11.2 .9 & O1 & $\mathrm{P} 1$ & $\mathrm{~T} 2$ & 1.89 & 1.89 \\
\hline & 11.2 .10 & $\mathrm{O} 7$ & $\mathrm{P} 2$ & T6 & 0.63 & 0.63 \\
\hline & 11.2 .11 & O5 & $\mathrm{P} 3$ & $\mathrm{~T} 7$ & 1.26 & 1.26 \\
\hline & 11.2 .12 & O5 & $\mathrm{P} 1$ & $\mathrm{~T} 4$ & 1.26 & 1.26 \\
\hline
\end{tabular}

The theoretical framework (Fig. 2 and Fig. 3) and scoring measures (Table 2) are different for GM and GBL. Besides, the significance of the total score and each 1 score 
are different due to the different weights of construction techniques. Therefore it is inappropriate to make direct use of Tables 4 and 5 for cross-sectional studies, so the Coefficient of Variation (CV) is introduced.

\subsection{Coefficient of Variation}

The $\mathrm{CV}$ is a measure of dispersion of data relative to the mean[44]. It makes direct use of the information contained in the index to obtain an index weight which also makes it an objective method of system empowerment. The basic approach of this method is based on the evaluation index system and a greater index difference reflects more difficulties in achieving certain targets.

The basic form of CV expression " $\mathrm{K}$ " is expressed in Eq.1:

$$
\mathrm{K}=\frac{\sigma}{\mathrm{x}}
$$

Where " $\sigma$ " represents the standard deviation of the whole sample; " $x$ " represents the mean of the whole sample.

Scores summarized for the Objective dimension and Time dimension for GBL \& GM are shown in Table 6.

Table 6: Numerical analysis of coefficient of variation of the project under GBL and GM

\begin{tabular}{|c|c|c|c|c|c|c|c|c|c|c|c|c|c|c|c|}
\hline \multirow{3}{*}{$\begin{array}{c}\text { Scor } \\
\mathrm{e}\end{array}$} & \multicolumn{8}{|c|}{ Time dimension } & \multicolumn{7}{|c|}{ Objective dimension } \\
\hline & $\mathrm{P}$ & $\mathrm{T} 1$ & $\mathrm{~T} 2$ & $\mathrm{~T} 3$ & $\mathrm{~T} 4$ & $\mathrm{~T} 5$ & T6 & $\mathrm{T} 7$ & $\mathrm{O} 1$ & $\mathrm{O} 2$ & $\mathrm{O} 3$ & $\mathrm{O}$ & $\mathrm{O}$ & $\mathrm{O}$ & $\mathrm{O}$ \\
\hline & & & & & & & & & & & & 4 & 5 & 6 & 7 \\
\hline \multirow{10}{*}{ GBL } & $\mathrm{P} 1$ & 1. & 3.3 & 7. & 1 & 1. & 0 & 0 & 4.6 & 1.4 & 0 & 0 & 5. & 0 & 3. \\
\hline & & 9 & & 8 & & 9 & & & & & & & 1 & & 8 \\
\hline & $\mathrm{P} 2$ & 0 & 0 & 0 & 5. & 1. & 2. & 0 & 1.3 & 0 & 1.4 & 2. & 0 . & 5. & 0 \\
\hline & & & & & 6 & 1 & 0 & & & & & 0 & 8 & 2 & \\
\hline & P3 & 0 & 4.2 & 0 & 0. & 1 & 0 & 2.3 & 1.3 & 0 & 2.4 & 1. & 1 & 4. & 0 \\
\hline & & & & & 9 & & & & & & & 4 & & 0 & \\
\hline & $\mathrm{P} 4$ & 0 & 0 & 0 & 0 & 0 & 6. & 0 & 0 & 0 & 0 & 6. & 0 & 0 & 0 \\
\hline & & & & & & & 0 & & & & & 0 & & & \\
\hline & P5 & 0 & 0 & 0 & 16 & 2. & 0. & 0 & 0 & 3.6 & 11. & 0 & 0 & 5. & 0 \\
\hline & & & & & & 7 & 7 & & & & 2 & & & 1 & \\
\hline
\end{tabular}




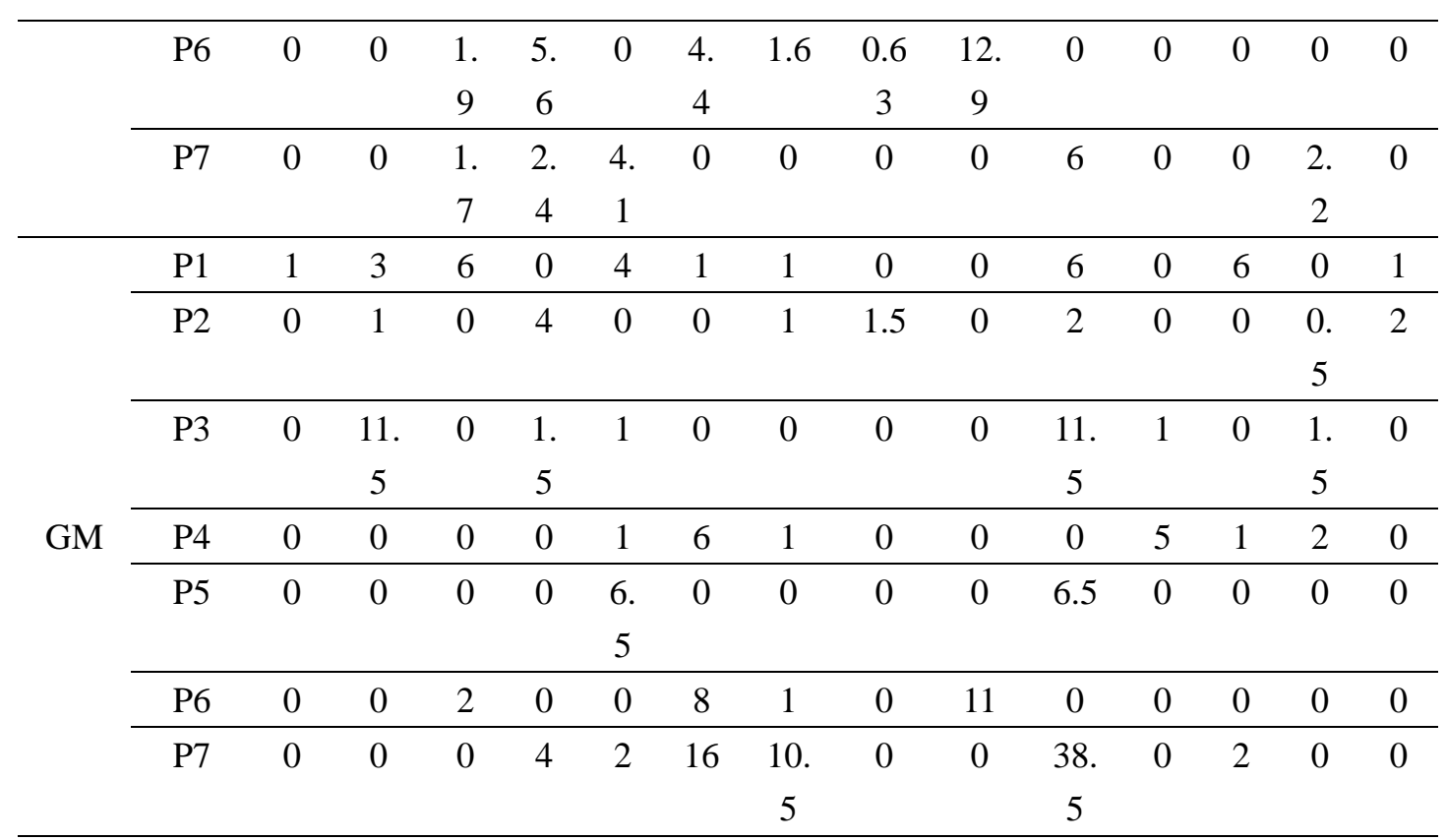

The targets Tx and Ox which are the most volatile in influencing scores can be extracted and they will be the key targets which worth the investment efforts for the developers. On the other hand, Tx with Ox is also the refining and improving direction and a concern of the standard legislative bodies. The mean values analysis of P-O \& P$\mathrm{T}$ in GBL and GM are shown in Fig. 4, and the normalized coefficient of variation analysis of P-O \& P-T in GBL and GM are shown in Fig. 5. 


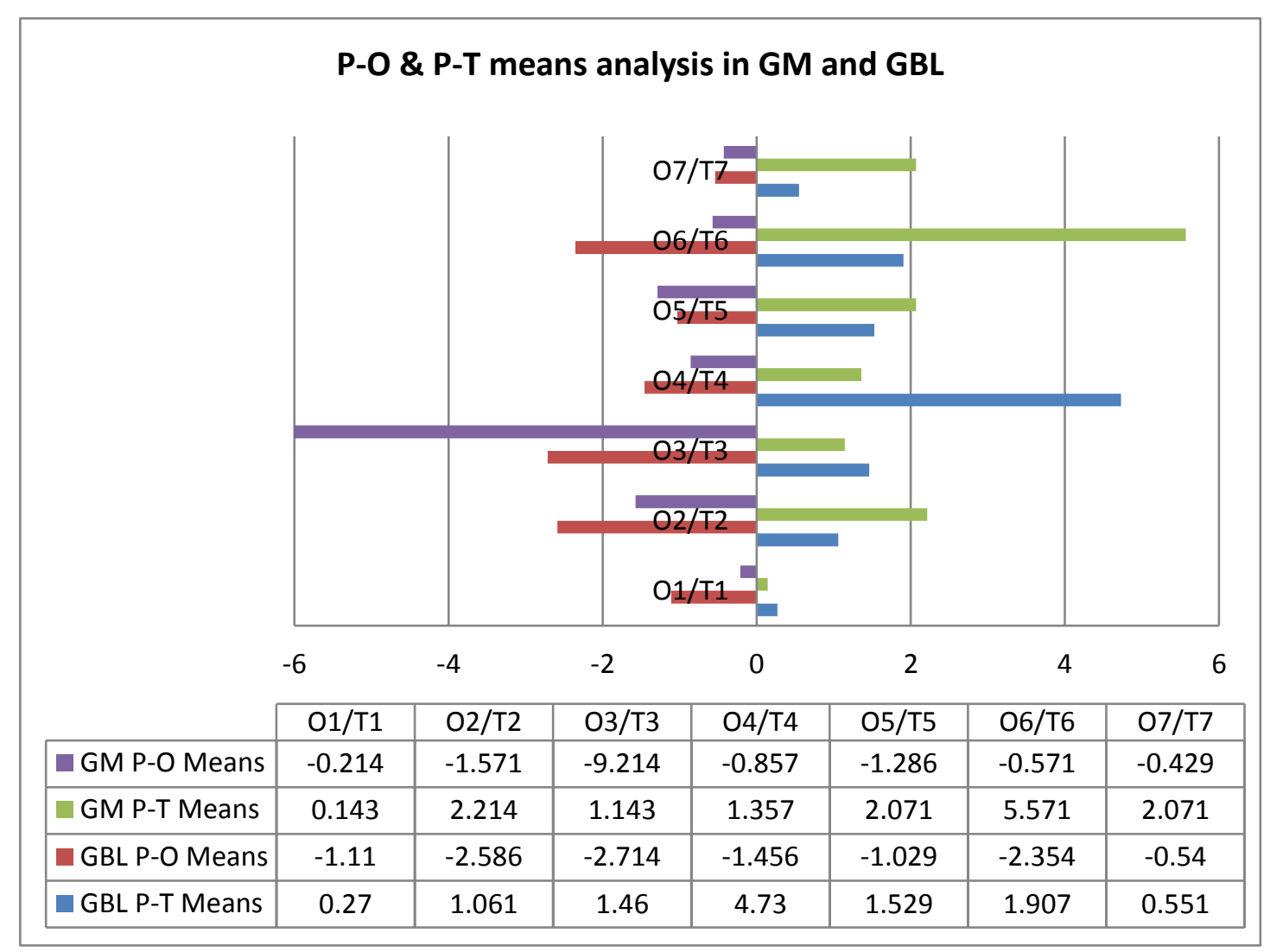

Fig. 5: P-O \& P-T mean value analysis in GM and GBL

Fig. 5 shows that, in the P-O dimension, the GBL makes relatively more effort in $\mathrm{O} 2, \mathrm{O} 3$ while the GM does obviously in O3. Both GM and GBL show less attention in $\mathrm{T} 1$ in the score distribution in P-T dimension. The GBL has paid more attention to T4 than T6 while the GM represents the reverse (T6>T4). In general both GM and GBL have less score weights on $\mathrm{O} 1$ and $\mathrm{T} 1$ but more on $\mathrm{O} 2$ to O6. Both GM and GBL focuse on the green technology application at the design phase and construction phase but neglect that at the pre-design phase and the completion and test phase. The GM much considers the energy saving while the GBL makes balanced requirements on energy and water. 


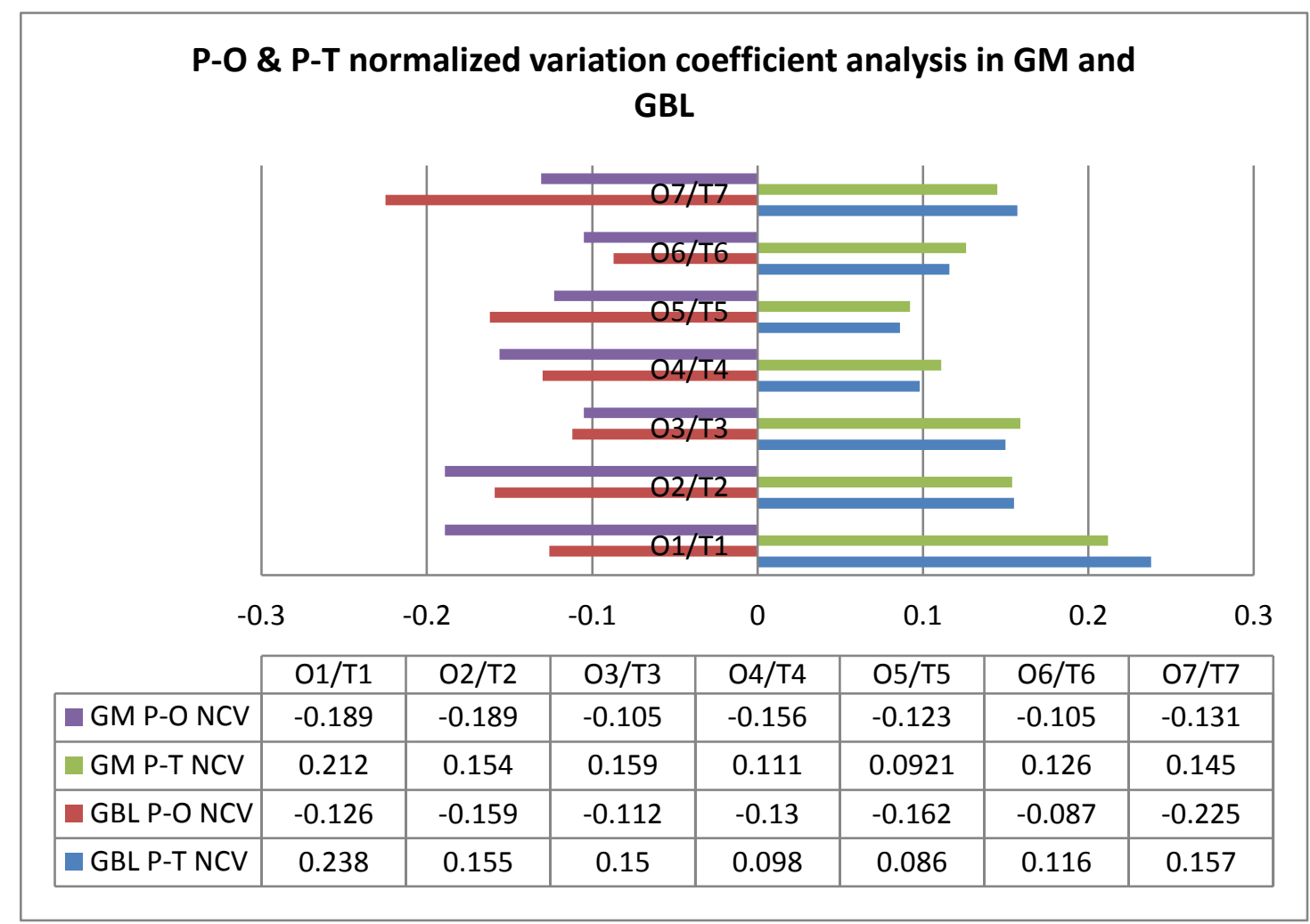

Fig. 6: P-O \& P-T normalized coefficient of variation analysis in GM and GBL

It can be seen in Fig. 6 that the GBL represents the largest volatility at 07 while the O-dimension of the GM is more balanced in general. In both GM and GBL, items in O-dimension fluactuate more than the items in the T-dimension. In the P-T dimension analysis, the fluctuations in both GM and GBL are similar to each other, showing the $\mathrm{T} 1$ and the $\mathrm{T} 7$ with largest volatility than that in $\mathrm{T} 2$ to $\mathrm{T} 6$ stages.

In summary, the assessment results of both GM and GBL of the same project show the fluctuation characteristics. The GBL shows controllability in the main items so to prevent high-score-driven technology applications. The GM pays the highest attention on the item 'energy saving'. The LCA application on green building assessment is insufficient in both GM and GBL. This is caused by the lack of an international agreement on datasets[51, 52].

\subsection{Scoring centroid system}

There are different design emphases for different projects. This can be presented by the deviation of the scoring centroid system of the project. Similarly, the default 
deviation of GM and GBL standards can also be presented. In order to study the compliance level of the project to specific standards, the project vector (centroid vector of the actual score), the ideal vector $(1,1,1)$ and the standard vectors (centroid vector of the total score) can be calculated.

The centroid is considered as a hypothetical centre point of the scoring centroid system. The score distribution of the project is simulated as the spatial distribution of mass composition where the $\mathrm{Oi}-\mathrm{Pi}-\mathrm{Ti}$ coordinate refers to the location of $\mathrm{Xi}-\mathrm{Yi}-\mathrm{Zi}$, and the score of (Oi-Pi-Ti) refers to the mass composition weight of M (Xi-Yi-Zi). Assume a mass system with composition of $m_{1}, m_{2}, m_{3}, \ldots m_{n}$, and the sagittal diameter of each particle with respect to an origin " $O$ " is $r_{1}, r_{2}, r_{3}, \ldots, r_{n}$ respectively, then the centroid vector denoted as $\mathrm{R} \sigma$ can be calculated as Eq. 2 and Eq. 3.

$$
\begin{aligned}
& \mathrm{R} \sigma=\frac{\sum \mathrm{Mi} \times \mathrm{ri}}{\mathrm{M}} \\
& \mathrm{M}=\sum_{\mathrm{i}=1}^{\mathrm{n}} \mathrm{m}_{\mathrm{i}}
\end{aligned}
$$

Where $M$ represents the total mass quantity of the mass system, "R $\sigma$ " represents the synthetic centroid vector of the mass system.

The relative position of each mass composition is independent according to a specific standard framework. The centroid vector of the mass system is only decided by the project scores which reflect its green investment under a specific standard. The project's vectors under GM and GBL, together with the standards' vector of GM and GBL are shown in Table 7.

\begin{tabular}{|c|c|c|c|c|c|c|}
\hline \multicolumn{2}{|c|}{$\begin{array}{l}\text { Secondary } \\
\text { indicators }\end{array}$} & $\begin{array}{l}\text { Objective } \\
\text { coordinate }\end{array}$ & $\begin{array}{l}\text { Professional } \\
\text { coordinate }\end{array}$ & $\begin{array}{l}\text { Time co- } \\
\text { ordinate }\end{array}$ & $\begin{array}{c}\text { Actual score- } \\
\text { weighted }\end{array}$ & $\begin{array}{l}\text { Total score- } \\
\text { weighted }\end{array}$ \\
\hline \multicolumn{2}{|c|}{ Items } & $\mathrm{O}$ & $\mathrm{P}$ & $\mathrm{T}$ & AS & $\mathrm{TS}$ \\
\hline GBL & 4.2.1 & 1 & 2 & 2 & 0 & 3.99 \\
\hline
\end{tabular}

Table 7: The scoring centroid system of the project under GM and GBL 


\begin{tabular}{|c|c|c|c|c|c|c|}
\hline & 4.2 .2 & 1 & 1 & 3 & 1.89 & 1.89 \\
\hline & 4.2 .3 & 1 & 3 & 2 & 1.26 & 1.26 \\
\hline \multirow[t]{3}{*}{ GM } & $1-1$ & 3 & 3 & 2 & 11.5 & 20 \\
\hline & $1-2 a$ & 3 & 7 & 6 & 8 & 8 \\
\hline & $1-2 b$ & 3 & 1 & 3 & 4 & 4 \\
\hline $\begin{array}{r}\text { Sym- } \\
\text { bol }\end{array}$ & $\begin{array}{l}\text { Item } \\
\text { (i) }\end{array}$ & $\mathrm{O}(\mathrm{i})$ & P (i) & $\mathrm{T}$ (i) & AS (i) & WS (i) \\
\hline
\end{tabular}

The modelling of a centroid vector under the scoring centroid system is shown in Eq.2.

$$
\mathrm{R} \sigma=\frac{\sum \mathrm{Mi} \times \mathrm{ri}}{\mathrm{M}}
$$

Where $\mathrm{R} \sigma$ represents the centroid vector of the scoring centroid system.

The centroid coordinate positions of the project in the OPT coordinate system can be described in Eqs. 4, 5,6

$$
\begin{aligned}
& \mathrm{Ro}=\frac{\sum \mathrm{AS}(\mathrm{i}) * \mathrm{O}(\mathrm{i})}{\sum \mathrm{AS}} \\
& \mathrm{Rp}=\frac{\sum \mathrm{AS}(\mathrm{i}) * \mathrm{P}(\mathrm{i})}{\sum \mathrm{AS}} \\
& \mathrm{Rt}=\frac{\sum \mathrm{AS}(\mathrm{i}) * \mathrm{~T}(\mathrm{i})}{\sum \mathrm{AS}}
\end{aligned}
$$

Where Ro, Rp, Rt represent the centroid vector in each dimension.

The project centroid vector can be expressed in Eq. 7 . 


$$
\overrightarrow{\mathrm{Ropt}}=\frac{\sum \mathrm{AS}(\mathrm{i}) * \overrightarrow{\mathrm{OPT}(1)}}{\sum \mathrm{AS}}
$$

The final model for the project vector in the OPT coordinate system can be derived by expansion of the above equation combined with Table 8, as shown in Eq. 8 below.

$$
\overrightarrow{\mathrm{Ropt}}=\frac{1}{\sum \mathrm{AS}}\left(\sum \mathrm{AS}(\mathrm{i}) * \mathrm{O}(\mathrm{i}), \sum \mathrm{AS}(\mathrm{i}) * \mathrm{P}(\mathrm{i}), \sum \mathrm{AS}(\mathrm{i}) * \mathrm{~T}(\mathrm{i})\right)=(\mathrm{Ca}, \mathrm{Cb}, \mathrm{Cc})
$$

Where $\overrightarrow{\mathrm{Ropt}}$ represents the final expression of the project centroid vector.

Similarly, the standards' centroid vectors (GM\& GBL) can be expressed in Eq. 9.

$$
\overrightarrow{\mathrm{WRopt}}=\frac{1}{\sum \mathrm{WS}}\left(\sum \mathrm{WS}(\mathrm{i}) * \mathrm{O}(\mathrm{i}), \sum \mathrm{WS}(\mathrm{i}) * \mathrm{P}(\mathrm{i}), \sum \mathrm{WS}(\mathrm{i}) * \mathrm{~T}(\mathrm{i})\right)=(\mathrm{Wa}, \mathrm{Wb}, \mathrm{Wc})
$$

Where $\overrightarrow{\mathrm{WRopt}}$ represents the centroid vectors of the green building standards.

The compliance coefficient of the project in accordance with the unit vector $(1,1$, 1) which represents the absolute balance direction of the each dimention (same angle of $45^{\circ}$ between the three axises) in the OPT coordinate system can be expressed as Eqs. $10-12$.

$$
\begin{gathered}
\alpha o=\cos ^{-1}(\overrightarrow{\mathrm{Ropt}}, \overrightarrow{\mathrm{Spt}})=\cos ^{-1} \frac{\mathrm{Ca}}{\sqrt{\mathrm{Ca}^{2}+\mathrm{Cb}^{2+} \mathrm{Cc}^{2}}}= \\
\cos ^{-1} \frac{\sum \mathrm{AS}(\mathrm{i}) * \mathrm{O}(\mathrm{i})}{\sqrt{\left[\sum \mathrm{WS}(\mathrm{i}) * \mathrm{O}(\mathrm{i})\right]^{2}+\left[\sum \mathrm{WS}(\mathrm{i}) * \mathrm{P}(\mathrm{i})\right]^{2+}\left[\sum \mathrm{WS}(\mathrm{i}) * \mathrm{~T}(\mathrm{i})\right]^{2}}}
\end{gathered}
$$

$$
\alpha p=\cos ^{-1}(\overrightarrow{\mathrm{Ropt}}, \overrightarrow{\mathrm{Sot}})=\cos ^{-1} \frac{\mathrm{Cb}}{\sqrt{\mathrm{Ca}^{2}+\mathrm{Cb}^{2+} \mathrm{Cc}^{2}}}=
$$




$$
\cos ^{-1} \frac{\sum \mathrm{AS}(\mathrm{i}) * \mathrm{P}(\mathrm{i})}{\sqrt{\left[\sum \mathrm{WS}(\mathrm{i}) * \mathrm{O}(\mathrm{i})\right]^{2}+\left[\sum \mathrm{WS}(\mathrm{i}) * \mathrm{P}(\mathrm{i})\right]^{2+}\left[\sum \mathrm{WS}(\mathrm{i}) * \mathrm{~T}(\mathrm{i})\right]^{2}}}
$$

(11)

$$
\begin{gathered}
\alpha t=\cos ^{-1}(\overrightarrow{\text { Ropt }}, \overrightarrow{\text { Sop }})=\cos ^{-1} \frac{\mathrm{Cc}}{\sqrt{\mathrm{Ca}^{2}+\mathrm{Cb}^{2+} \mathrm{Cc}^{2}}}= \\
\cos ^{-1} \frac{\sum \mathrm{AS}(\mathrm{i}) * \mathrm{~T}(\mathrm{i})}{\sqrt{\left[\sum \mathrm{WS}(\mathrm{i}) * \mathrm{O}(\mathrm{i})\right]^{2}+\left[\sum \mathrm{WS}(\mathrm{i}) * \mathrm{P}(\mathrm{i})\right]^{2+}\left[\sum \mathrm{WS}(\mathrm{i}) * \mathrm{~T}(\mathrm{i})\right]^{2}}}
\end{gathered}
$$

Where $\overrightarrow{S o p t} \overrightarrow{S p t} \overrightarrow{S p t} \overrightarrow{S p t}$ represent the ideal deviation vector of $(1,1,1),(1,0,0)$, $(0,1,0),(0,0,1)$. Vector $(\alpha \mathrm{o}, \alpha \mathrm{p}, \alpha \mathrm{t})$ represents the project deviation in the OPT coordinate system.

$$
\begin{gathered}
\rho(\text { opt })=\cos (\overrightarrow{\text { Ropt }}, \overrightarrow{\text { Sopt }})=\frac{\mathrm{Ca}+\mathrm{Cb}+\mathrm{Cc}}{\sqrt{3 *\left(\mathrm{Ca}^{2}+\mathrm{Cb}^{2+} \mathrm{Cc}^{2}\right)}}= \\
\frac{\sum \mathrm{AS}(\mathrm{i}) * \mathrm{~T}(\mathrm{i})+\sum \mathrm{AS}(\mathrm{i}) * \mathrm{P}(\mathrm{i})+\sum \mathrm{AS}(\mathrm{i}) * \mathrm{~T}(\mathrm{i})}{\sqrt{\left[\sum \mathrm{WS}(\mathrm{i}) * \mathrm{O}(\mathrm{i})\right]^{2}+\left[\sum \mathrm{WS}(\mathrm{i}) * \mathrm{P}(\mathrm{i})\right]^{2+}\left[\sum \mathrm{WS}(\mathrm{i}) * \mathrm{~T}(\mathrm{i})\right]^{2}}}
\end{gathered}
$$

Where $\rho$ (opt) represents the compliance coefficient of the project in accordance with the ideal deviation vector $(1,1,1)$.

The project reflects its ideal balanced status on the three dimensions of OPT when $\rho(\mathrm{opt})$ takes the maximum value of 1 . Meanwhile, the green building evaluation criteria has its own proprietary dimension when $(\mathrm{Ca}, \mathrm{Cb}, \mathrm{Cc})$ is replaced by $(\mathrm{Wa}, \mathrm{Wb}, \mathrm{Wc})$ based on the above calculation of ( $\alpha \mathrm{o}, \alpha \mathrm{p}, \alpha \mathrm{t})$. Then the Moment of Inertia (MI) in the scoring centroid system is introduced for the calculation of the project's deviation from the GM and GBL.

\subsection{Moment of Inertia}

The magnitude of the MI depends on the shape of the mass system, the mass dis- 
tribution and the shaft position. Each mass system reflects the project's and the standards' inherent characteristics. The degree of compliance of the projects to GM and GBL can be obtained by analysing the centroid vectors' deviations. The compliance coefficient indicates that the project design should be in line with the local economic, technological and natural environment and other regional characteristics reflected by the local green building standard.

The basic definition of the moment of inertia in a mass system is shown in Eq. 14.

$$
\mathrm{I}=\sum_{\mathrm{i}}^{\mathrm{n}} \mathrm{MR}^{2}
$$

In order to ensure the coordinate comparison between GM and GBL, take the proportion of the project actual score to total score for each indicator as the input parameters, rather than the actual scores, because each 1 point in GM and GBL shows a different unit investment. The proportion of the project actual score to total score makes a more objective reflection of the green building effort.

The standard deviations can be achieved by replacing $(\mathrm{Ca}, \mathrm{Cb}, \mathrm{Cc})$ with $(\mathrm{Wa}, \mathrm{Wb}$, Wc) as shown in Eq. 15.

$$
\overrightarrow{\mathrm{WRopt}}=\frac{1}{\Sigma \mathrm{WS}}\left(\sum \mathrm{WS}(\mathrm{i}) * \mathrm{O}(\mathrm{i}), \sum \mathrm{WS}(\mathrm{i}) * \mathrm{P}(\mathrm{i}), \sum \mathrm{WS}(\mathrm{i}) * \mathrm{~T}(\mathrm{i})\right)=(\mathrm{Wa}, \mathrm{Wb}, \mathrm{Wc})
$$

Where $\overrightarrow{\text { WRopt }}$ represents the standards' centroid vectors.

The project's compliance coefficient to a standard can be calculated by the combination of I and $\overrightarrow{\mathrm{WRopt}}$ as shown in Eq. 16 .

$$
\Delta=\frac{\sum A S}{\sum W S} * \frac{\left|\begin{array}{cc}
\mathrm{Cb} & \mathrm{Cc} \\
\mathrm{Wb} & \mathrm{Wc}
\end{array}\right|^{2}+\left|\begin{array}{cc}
\mathrm{Cc} & \mathrm{Ca} \\
\mathrm{Wc} & \mathrm{Wa}
\end{array}\right|^{2}+\left|\begin{array}{cc}
\mathrm{Ca} & \mathrm{Cb} \\
\mathrm{Wa} & \mathrm{Wb}
\end{array}\right|^{2}}{\mathrm{Wa}^{2}+\mathrm{Wb}^{2}+\mathrm{Wc}^{2}} * 100 \%
$$


Where $\sum$ WS represents the total weight of a standard; $\sum$ AS represents the total weight of a project under a specific standard.

The expansion of Eq. 16 can be described in Eqs. 17-20 below.

$\mathrm{M}=\left\{\left[\sum \mathrm{AS}(\mathrm{i}) * \mathrm{P}(\mathrm{i})\right] *\left[\sum \mathrm{WS}(\mathrm{i}) * \mathrm{~T}(\mathrm{i})\right]-\left[\sum \mathrm{AS}(\mathrm{i}) * \mathrm{~T}(\mathrm{i})\right] *\left[\sum \mathrm{WS}(\mathrm{i}) * \mathrm{P}(\mathrm{i})\right]\right\}^{2}$

$\mathrm{N}=\left\{\left[\sum \mathrm{AS}(\mathrm{i}) * \mathrm{~T}(\mathrm{i})\right] *\left[\sum \mathrm{WS}(\mathrm{i}) * \mathrm{O}(\mathrm{i})\right]-\left[\sum \mathrm{AS}(\mathrm{i}) * \mathrm{O}(\mathrm{i})\right] *\left[\sum \mathrm{WS}(\mathrm{i}) * \mathrm{~T}(\mathrm{i})\right]\right\}^{2}$

$\mathrm{S}=\left\{\left[\sum \mathrm{AS}(\mathrm{i}) * \mathrm{O}(\mathrm{i})\right] *\left[\sum \mathrm{WS}(\mathrm{i}) * \mathrm{P}(\mathrm{i})\right]-\left[\sum \mathrm{AS}(\mathrm{i}) * \mathrm{P}(\mathrm{i})\right] *\left[\sum \mathrm{WS}(\mathrm{i}) * \mathrm{O}(\mathrm{i})\right]\right\}^{2}$

$$
\mathrm{T}=\left[\sum \mathrm{WS}(\mathrm{i}) * \mathrm{P}(\mathrm{i})\right]^{2}+\left[\sum \mathrm{AS}(\mathrm{i}) * \mathrm{P}(\mathrm{i})\right]^{2}+\left[\sum \mathrm{WS}(\mathrm{i}) * \mathrm{O}(\mathrm{i})\right]^{2}
$$

The compliance coefficient model can be expressed in Eq. 21 .

$$
\Delta=\frac{\sum \mathrm{AS}}{\sum \mathrm{WS}} * \frac{\mathrm{M}+\mathrm{N}+\mathrm{S}}{\mathrm{T}} * 100 \%
$$

Where $\Delta$ represents the compliance coefficient of the project to specific green building standards.

\subsection{Practical application in the case study project}

The analysis result of the case study project based on the developed OPT model can be achieved in combination with the project data in Table 8 and Table 9.

Table 8: Analysis result of the GM \& GBL standards in the developed OPT model

\begin{tabular}{llll}
\hline Standard & Centroid & Sagittal & Angle deviation \\
& coordinate & diameter & to ideal vector \\
\hline GBL & 3.627869 & 6.706489 & $\alpha=0.687997$ \\
& 3.738959 & & \\
\hline
\end{tabular}




\begin{tabular}{llll}
\hline & 4.223240 & & \\
\hline GM & 3.321168 & 7.570561 & $\alpha=0.609066$ \\
& 4.751825 & & \\
& 4.868613 & & \\
&
\end{tabular}

Radial vectors for GBL and GM green building standards are (3.627869, 3.738959, $4.22324)$ and $(3.321168,4.751825,4.868613)$ respectively. It indicates that GBL shows a more balanced development in the three dimensions while GM showed a relatively greater coverage on the Professional and Time dimensions than for the Objective dimension.

Table 9: Analysis result of the case project under GM \& GBL in the developed OPT model

\begin{tabular}{lllllll}
\hline $\begin{array}{l}\text { Project \& } \\
\text { Standard }\end{array}$ & $\begin{array}{l}\text { Centroid } \\
\text { coordinate }\end{array}$ & $\begin{array}{l}\text { Sagittal } \\
\text { diameter }\end{array}$ & $\begin{array}{l}\text { Quality } \\
\text { ratio }\end{array}$ & $\begin{array}{l}\text { Angles } \\
\text { to axis }\end{array}$ & $\begin{array}{l}\text { Angle deviation } \\
\text { to standard vector }\end{array}$ & $\begin{array}{c}\text { Compliance } \\
\text { coefficient }\end{array}$ \\
\hline GBL & 3.653883 & 6.892116 & 0.802122 & 1.012014 & $\alpha=0.067656$ & 1.270880 \\
& 3.940851 & & & 0.962109 & & \\
& 4.315100 & & & 0.894265 & & \\
\hline GM & 3.392157 & 7.631810 & 0.744526 & 1.110207 & $\alpha=0.155491$ & 0.310535 \\
& 4.745098 & & & 0.899818 & & \\
& 4.921569 & & & 0.869936 & & \\
\hline
\end{tabular}

Although the project has obtained the highest rating awards of both GM and GBL, it exhibits significant differences between the compliance level to GM and GBL in the OPT coordinate system. Meanwhile, the project centroid coordinates in the theoretical frameworks of GBL and GM are $(3.653883,3.940851,4.3151)$ and (3.392157, $4.745098,4.921569)$ respectively, showing a more balanced performance under GBL. This is because the more detailed and balanced secondary indicators in GBL compared to those of GM. The project has a compliance coefficient of 1.270880 in GBL and a 
compliance coefficient of 0.310535 in GM. It shows that, although the project has introduced many green building technologies according to both GM and GBL rating systems, the project investment direction is still in favour of the Singapore GM framework and the project is more biased towards Singapore green building design requirements.

\section{Conclusions and Outlook}

This study presents a comparison of the China GBL and Singapore GM standards based on a real project in Chongqing and to identify their characteristics and explore the inner balance of both standards in the OPT dimensions. A multidimensional OPT model for green building assessment is developed by the introduction of the Coefficient of Variation (CV) and Moment of Inertia ( MI) in the scoring centroid system. A model of the compliance coefficient is built up for the calculation of the project's compliance level to the corresponding green building standard. It enlightens a new method of green building design. The main conclusions are drawn as follows:

- Both GM and GBL show a peak score distribution on the design and construction phases of a project whilst paying little attention to the pre-design and completion phases. The whole process assessment of green buildings should be the direction for the future green building standard setting.

- A project will show different fluctuation characteristics under different green building standards, which is reflected by the coefficient of variation. GBL shows good controllability to avoid the application of impractical green technologies whose only purpose is achieving high scores.

- The Compliance Coefficient of the project representing the absolute balance direction in the OPT coordinate system is introduced. It can demonstrate an intuitive compliance status of a practical project in accordance to a specific green building standard. The developed OPT model provides quantified and practical guidance for both green buildings design and assessment.

The "local" project can be determined through the compliance coefficient of the project to a specific standard. The compliance coefficient provides important indicator 
for green building assessment besides scores.

Meanwhile, the "balanced" level of the current standard can be found out by its vector deviation to the the unit vector $(1,1,1)$. The vector deviation provides theoretical references on the possible strong and weak aspects of the current standard for the latter standard revision.

In conclusion, the model can be used for the improvement of the exisitng green building for both green building designers and policy-makers with benefit of the function of compliance degrees analysis.

\section{Acknowledgement}

The authors would like to thank the financial support from the Natural Science Foundation of China (Project No. 51408079) and the technical support from the Singarpore City Development Limited. Mr Yongqiang Li would like to thank the China Scholarship Council for the sponsorship for a one-year academic visiting study at the University of Reading during 2015-2016.

\section{References}

[1] S. Suh, S. Tomar, M. Leighton, J. Kneifel, Environmental performance of green building code and certification systems, Environmental science \& technology, 48 (5) (2014) 2551-2560.

[2] B. Commission, Our common future, Chapter 2: Towards sustainable development, World Commission on Environment and Development (WCED). Geneva: United Nation, (1987).

[3] J. Glass, A.R. Dainty, A.G. Gibb, New build: materials, techniques, skills and innovation, Energy Policy, 36 (12) (2008) 4534-4538.

[4] C. Karkanias, S. Boemi, A. Papadopoulos, T. Tsoutsos, A. Karagiannidis, Energy efficiency in the Hellenic building sector: An assessment of the restrictions and perspectives of the market, Energy Policy, 38 (6) (2010) 2776-2784.

[5] F. Fuerst, P. McAllister, The impact of Energy Performance Certificates on the rental and capital values of commercial property assets, Energy Policy, 39 (10) (2011) 6608-6614.

[6] S. Sedlacek, G. Maier, Can green building councils serve as third party governance institutions? An economic and institutional analysis, Energy Policy, 49 (2012) 479-487.

[7] Y. Qin, B. Lin, Y. Zhu, Study on China Green Building Rating System, ARCHITECTURE, 3 (2007) 68-71(in Chinese).

[8] https://archive.epa.gov/greenbuilding/web/html/, in, 2016.

[9] A. Haapio, P. Viitaniemi, A critical review of building environmental assessment tools, Environmental impact assessment review, 28 (7) (2008) 469-482.

[10] C.J. Kibert, Sustainable construction: green building design and delivery, John Wiley \& Sons, 2008. 
[11] M. Xiaoping, L. Huimin, L. Qiming, A comparison study of mainstream sustainable/green building rating tools in the world, in: Management and Service Science, 2009. MASS'09. International Conference on, IEEE, 2009, pp. 1-5.

[12] U.G.B. Council, Green building design and construction, US Green Building Council, 2009.

[13] J.A. Todd, D. Crawley, S. Geissler, G. Lindsey, Comparative assessment of environmental performance tools and the role of the Green Building Challenge, Building Research \& Information, 29 (5) (2001) 324-335.

[14] J. Yudelson, The green building revolution, Island Press, 2010.

[15] J. Yudelson, Greening existing buildings, McGraw-Hill New York, 2010.

[16] B. Global, BREEAM New Construction Non-Domestic Buildings Technical Manual, in, Hertfordshire, UK: BRE Global Ltd, 2011.

[17] J. Ferreira, M.D. Pinheiro, J. de Brito, Portuguese sustainable construction assessment tools benchmarked with BREEAM and LEED: An energy analysis, Energy and Buildings, 69 (2014) 451-463.

[18] S. Azhar, W.A. Carlton, D. Olsen, I. Ahmad, Building information modeling for sustainable design and LEED ${ }^{\circledR}$ rating analysis, Automation in construction, 20 (2) (2011) 217-224.

[19] J.C. Cheng, L.J. Ma, A Study of the Relationship between Credits in the LEED-EB\&OM Green Building Rating System, IACSIT International Journal of Engineering and Technology, 5 (4) (2013) 5.

[20] O.S. Alshamrani, K. Galal, S. Alkass, Integrated LCA-LEED sustainability assessment model for structure and envelope systems of school buildings, Building and Environment, 80 (2014)61-70.

[21] D. Castro-Lacouture, J.A. Sefair, L. Flórez, A.L. Medaglia, Optimization model for the selection of materials using a LEED-based green building rating system in Colombia, Building and Environment, 44 (6) (2009) 1162-1170.

[22] W. Wang, H. Rivard, R. Zmeureanu, Floor shape optimization for green building design, Advanced Engineering Informatics, 20 (4) (2006) 363-378.

[23] S. Schiavon, S. Altomonte, Influence of factors unrelated to environmental quality on occupant satisfaction in LEED and non-LEED certified buildings, Building and Environment, 77 (2014) 148-159.

[24] H.M. Günaydın, S.Z. Doğan, A neural network approach for early cost estimation of structural systems of buildings, International Journal of Project Management, 22 (7) (2004) 595-602.

[25] G.-H. Kim, S.-H. An, K.-I. Kang, Comparison of construction cost estimating models based on regression analysis, neural networks, and case-based reasoning, Building and environment, 39 (10) (2004) 1235-1242.

[26] M.W. Emsley, D.J. Lowe, A.R. Duff, A. Harding, A. Hickson, Data modelling and the application of a neural network approach to the prediction of total construction costs, Construction Management \& Economics, 20 (6) (2002) 465-472.

[27] A. Reith, M. Orova, Do green neighbourhood ratings cover sustainability?, Ecological Indicators, 48 (2015) 660-672.

[28] M. Kennedy, V.-N. Dinh, B. Basu, Analysis of consumer choice for low-carbon technologies by using neural networks, Journal of Cleaner Production, 112 (2016) 3402-3412.

[29] S. Shin, S. Tae, J. Woo, S. Roh, The development of environmental load evaluation system of a standard Korean apartment house, Renewable and Sustainable Energy Reviews, 15 (2) (2011) 12391249.

[30] D.-X. Zhao, B.-J. He, C. Johnson, B. Mou, Social problems of green buildings: From the humanistic needs to social acceptance, Renewable and Sustainable Energy Reviews, 51 (2015) 15941609. 
[31] S. Lee, S. Tae, S. Roh, T. Kim, Green Template for Life Cycle Assessment of Buildings Based on Building Information Modeling: Focus on Embodied Environmental Impact, Sustainability, 7 (12) (2015) 16498-16512.

[32] C.A. Dean, B.D. Fath, B. Chen, Indicators for an expanded business operations model to evaluate eco-smart corporate communities, Ecological Indicators, 47 (2014) 137-148.

[33] X. Zhang, Green real estate development in China: State of art and prospect agenda-A review, Renewable and Sustainable Energy Reviews, 47 (2015) 1-13.

[34] B. Everitt, The Cambridge Dictionary of Statistics, Cambridge University Press, Cambridge, UK, (1998).

[35] G.F. Reed, F. Lynn, B.D. Meade, Use of coefficient of variation in assessing variability of quantitative assays, Clinical and diagnostic laboratory immunology, 9 (6) (2002) 1235-1239.

[36] H. Xiong, J. Wu, J. Chen, K-means clustering versus validation measures: a data-distribution perspective, Systems, Man, and Cybernetics, Part B: Cybernetics, IEEE Transactions on, 39 (2) (2009) 318-331.

[37] K. Zhou, S. Yang, Exploring the uniform effect of FCM clustering: A data distribution perspective, Knowledge-Based Systems, (2016).

[38] M. Tanaka, K. Matsuo, M. Enomoto, K. Mizuno, A sol particle homogeneous immunoassay for measuring serum cystatin C, Clinical biochemistry, 37 (1) (2004) 27-35.

[39] T.H. Alemseged, R. Tom, Evaluation of regional climate model simulations of rainfall over the Upper Blue Nile basin, Atmospheric Research, 161 (2015) 57-64.

[40] Y. Kwak, J.-H. Huh, Development of a method of real-time building energy simulation for efficient predictive control, Energy Conversion and Management, 113 (2016) 220-229.

[41] M. Massinon, B. Dumont, N. De Cock, S.O.T. Salah, F. Lebeau, Study of retention variability on an early growth stage herbaceous plant using a 3D virtual spraying model, Crop Protection, 78 (2015) 63-71.

[42] X. Wang, G. Wu, Z. Wu, Z. Dong, Q. Xie, Evaluation of prestressed basalt fiber and hybrid fiber reinforced polymer tendons under marine environment, Materials \& Design, 64 (2014) 721-728.

[43] S. Qi, Q. Ouyang, Q. Chen, J. Zhao, Real-time monitoring of total polyphenols content in tea using a developed optical sensors system, Journal of pharmaceutical and biomedical analysis, 97 (2014) 116-122.

[44] P. Lovie, Coefficient of variation, Encyclopedia of statistics in behavioral science, (2005).

[45] C.E. Brown, Coefficient of variation, in: Applied Multivariate Statistics in Geohydrology and Related Sciences, Springer, 1998, pp. 155-157.

[46] B. Majumder, K. Yagi, N. Yunes, Improved universality in the neutron star three-hair relations, Physical Review D, 92 (2) (2015) 024020.

[47] H.H. Örkcü, V.S. Özsoy, E. Aksoy, M.I. Dogan, Estimating the parameters of 3-p Weibull distribution using particle swarm optimization: A comprehensive experimental comparison, Applied Mathematics and Computation, 268 (2015) 201-226.

[48] N. Callegari Jr, F.B. Ribeiro, The spin-orbit resonant problem including core-mantle gravitational coupling, Computational and Applied Mathematics, 34 (2) (2015) 423-435.

[49] L.-J. Wang, F.-Q. Chen, Y. Sun, T. Mizusaki, M. Oi, Application of the Pfaffian Algorithm in the Nuclear Structure Study at High Spins, Acta Physica Polonica B, 46 (3) (2015).

[50] P.R.M. Céspedes, G.d.J.L. Cansteñs, E.R. Kriuchkova, L. Pérez, Propiedades dimensionales e inerciales del sistema fruto-pedicelo del mango relacionadas con la cosecha por vibración* Dimensional 
and inertial properties of the fruit-stem system of mango related with harvest by vibrationn.

[51] J. Reap, F. Roman, S. Duncan, B. Bras, A survey of unresolved problems in life cycle assessmentPart I goals and scope and inventory analysis, The International Journal of Life Cycle Assessment, 13 (4) (2008) 290-300.

[52] J. Reap, F. Roman, S. Duncan, B. Bras, A survey of unresolved problems in life cycle assessment, The International Journal of Life Cycle Assessment, 13 (5) (2008) 374-388. 